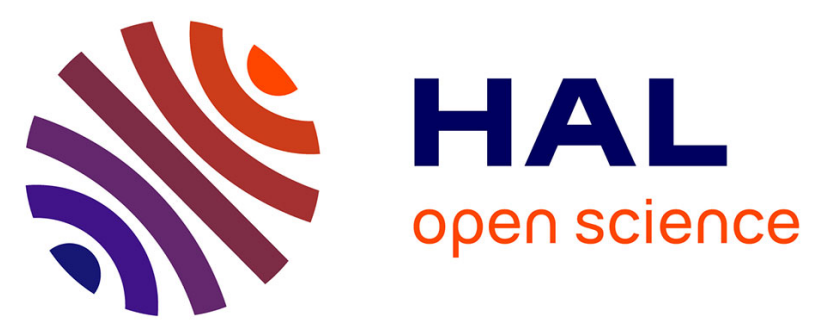

\title{
Synthesis and Structure-Activity Relationships of Ferrocenyl Tamoxifen Derivatives with Modified Side Chains.
}

\author{
A. Nguyen, S. Top, Pascal Pigeon, A. Vessieres, E.A. Hillard, M.A. Plamont, \\ M. Huche, C. Rigamonti, G. Jaouen
}

\section{To cite this version:}

A. Nguyen, S. Top, Pascal Pigeon, A. Vessieres, E.A. Hillard, et al.. Synthesis and Structure-Activity Relationships of Ferrocenyl Tamoxifen Derivatives with Modified Side Chains.. Chemistry - A European Journal, 2009, 15, pp.684-696. 10.1002/chem.200801108 . hal-00376089

\section{HAL Id: hal-00376089 \\ https://hal.science/hal-00376089}

Submitted on 26 May 2021

HAL is a multi-disciplinary open access archive for the deposit and dissemination of scientific research documents, whether they are published or not. The documents may come from teaching and research institutions in France or abroad, or from public or private research centers.
L'archive ouverte pluridisciplinaire HAL, est destinée au dépôt et à la diffusion de documents scientifiques de niveau recherche, publiés ou non, émanant des établissements d'enseignement et de recherche français ou étrangers, des laboratoires publics ou privés. 


\title{
Synthesis and Structure-Activity Relationships of Ferrocenyl Tamoxifen Derivatives with Modified Side Chains
}

Anh Nguyen, ${ }^{[\mathrm{a}]}$ Siden Top, ${ }^{[\mathrm{a}]}$ Pascal Pigeon, ${ }^{[\mathrm{a}]}$ Anne Vessières, ${ }^{*[\mathrm{a}]}$ Elizabeth A. Hillard, ${ }^{[\mathrm{a}]}$ Marie-Aude Plamont, ${ }^{[\mathrm{a}]}$ Michel Huché, ${ }^{[\mathrm{a}]}$ Clara Rigamonti, ${ }^{[\mathrm{b}]}$ and Gérard Jaouen ${ }^{[\mathrm{a}]}$

[a] Laboratoire de Chimie et Biochimie des Complexes Moléculaires, UMR CNRS 7576, Ecole Nationale Supérieure de Chimie de Paris, 11, rue Pierre et Marie Curie, 75231 Paris Cedex 05, France.

[b] Dipartimento di Chimica Organica e Industriale, Università degli Studi di Milano, via Venezian, 21 I-20133 Milan, Italy.

\begin{abstract}
We report here the synthesis and cell-proliferation properties of derivatives of the breast cancer drug tamoxifen, in which the $-\mathrm{O}\left(\mathrm{CH}_{2}\right)_{2} \mathrm{~N}\left(\mathrm{CH}_{3}\right)_{2}$ side chain, responsible for the drug's antiestrogenic properties, has been modified by a ferrocenyl moiety. We recently reported the diphenol compound 5, in which this amino chain had been replaced with an acyl-ferrocenyl $\left(-\mathrm{O}\left(\mathrm{CH}_{2}\right)_{2} \mathrm{C}(\mathrm{O})\left[\left(\eta^{5}-\mathrm{C}_{5} \mathrm{H}_{4}\right) \mathrm{FeCp}\right]\right)$ group, and which showed antiproliferative effects against both the hormone-dependent MCF-7 and -independent MDA-MB-231 breast cancer cell lines. We now report the results of a structure-activity relationship (SAR) study, in which the lateral chain length has been varied, the ketone group has been omitted, and the number of phenol groups has been varied. Compounds $\mathbf{1 - 4}$, with a side chain lacking the carbonyl function $\left(-\mathrm{O}\left(\mathrm{CH}_{2}\right)_{n}\left[\left(\eta^{5}-\mathrm{C}_{5} \mathrm{H}_{4}\right) \mathrm{FeCp}\right], n=1-4\right)$ and which show a decreasing affinity for ER $\alpha$ (ER=estrogen receptor) with increasing chain length, act as estrogens on MCF-7 cells, and mild cytotoxics on PC-3 prostate cancer cells, with $\mathrm{IC}_{50}$ values around $10 \mu \mathrm{M}$. The two monophenolic derivatives of $\mathbf{2}, \mathbf{2} \mathbf{a}$ and $\mathbf{2} \mathbf{b}$, which show a reduced affinity for ER $\alpha$ compared to 2, are also estrogenic, but are only slightly cytotoxic. Finally, we have reexamined compound $\mathbf{5}$ and discovered that its antiproliferative effect against the MCF-7 cell line does not arise from antiestrogenicity as we had originally suspected, but by means of a cytotoxic pathway. This compound is also sensitive to the number of phenol groups as cell death is diminished when one of the hydroxyl groups is omitted ( $5 \mathbf{a}$ and $\mathbf{5} \mathbf{b}$ ). Molecular modeling
\end{abstract}


studies of the ligand-ER $\alpha$ binding stability are broadly consistent with the experimental binding affinity results for compounds 2, 2 a, 2 b, 5, 5a and $5 \mathbf{b}$. Electrochemical experiments show that $\mathbf{1 - 4}, \mathbf{2} \mathbf{a}$, and $\mathbf{2} \mathbf{b}$ are stable to oxidation on the electrochemical timescale, unlike 5, $\mathbf{5} \mathbf{a}$, and $\mathbf{5} \mathbf{b}$, and that cytotoxicity is related to less positive phenol oxidation potentials. The SAR study shows that the presence of a ketone group and two phenol groups is necessary for strong receptor binding and cytotoxic effects, and that all compounds are estrogenic, despite the presence of a bulky side chain.

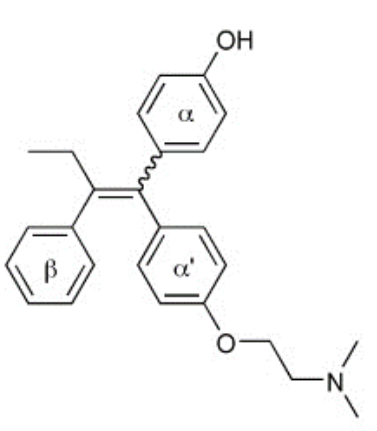

hydroxytamoxifen (OH-Tam)

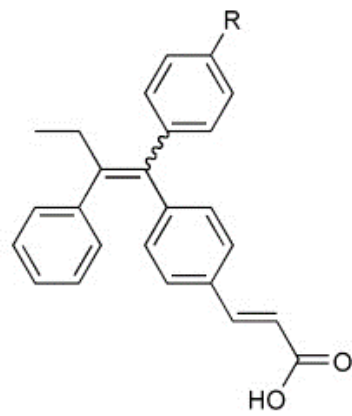

GW5638; $\mathrm{R}=\mathrm{H}$ GW7604; R $=\mathrm{OH}$

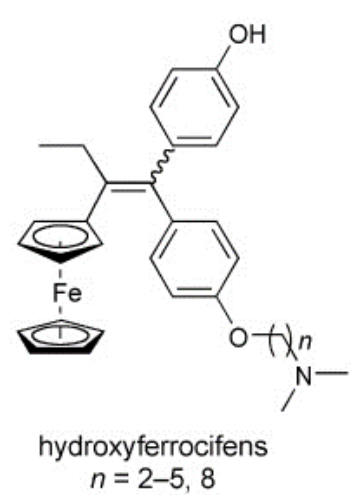

$n=2-5,8$

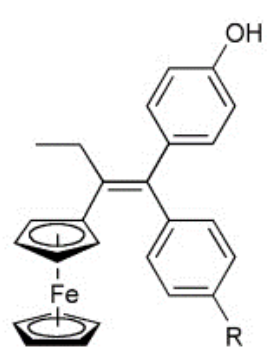

ferrocenyl phenols $\mathrm{R}=\mathrm{H}(\mathrm{Fc}-\mathrm{OH}), \mathrm{OH}(\mathrm{Fc}-\mathrm{diOH})$

\section{Introduction}

The breast cancer drug tamoxifen, as the hydroxylated metabolite, OH-Tam, can act as an estradiol $\left(\mathrm{E}_{2}\right)$ antagonist or agonist depending on the cellular context. ${ }^{[1]}$ It is currently accepted that the bioligand-estrogen receptor (ER) complex is not similarly recognized in all cells, and that tamoxifen resistance or estrogen-like activity in some tissues is related to this structure. ${ }^{[2-5]}$ According to X-ray diffraction analysis, $\mathrm{E}_{2}$ antagonism is broadly the result of the positioning of helix 12 of the ligand binding domain (LBD), which is displaced from the agonist position by molecules possessing bulky side chains, such as OH-Tam or pure antiestrogens. ${ }^{[6-8]}$ Therefore, control of the bioligand-ER structure through manipulation of the $-\mathrm{O}\left(\mathrm{CH}_{2}\right)_{2} \mathrm{~N}\left(\mathrm{CH}_{3}\right)_{2}$ group has been studied in view of discovering new pure or partial $\mathrm{E}_{2}$ antagonists. However, modification of substituents has usually led to a decrease in antiestrogenicity. ${ }^{[9-14]}$ For example, substitutions which diminish the basicity of the amine, by replacing the alkylamino side chain with $\mathrm{N}$-oxides, quaternary salts, or by adding fluorinated tethers, resulted in weakened ER binding, weakened antiproliferative potency, or even a proliferative effect on ER+ cells. ${ }^{[12-14]}$ The substitution of the amino side chain by carboxylic 
acids, such as in GW5638 and GW7604, has been the only important functional modification of the $\mathrm{OH}-\mathrm{Tam}$ side chain yielding strong antiestrogenic activity in the breast to date. ${ }^{[15-19]}$ The covalent tethering of ferrocene to the OH-Tam backbone has given rise to the "hydroxyferrocifens" and some active ferrocenyl phenols. ${ }^{[20-26]}$ The former, created by the replacement of the $\beta$ phenyl group of $\mathrm{OH}$-Tam with ferrocene, were designed to combine the antiestrogenicity of the OH-Tam scaffold with the cytotoxicity of a ferrocenyl group, ${ }^{[27,28]}$ resulting in compounds efficacious both on hormone-dependent and -independent breast cancer cells in vitro. The ferrocenyl phenols were designed by removing the hydroxyferrocifen side chain altogether, or by replacing it with a second hydroxyl group. These compounds are not antiestrogenic, due to the loss of the lateral chain, but show potent toxicity against both ER+ and ER- cancer cell lines. ${ }^{[25,29]}$ The generation of hydroxyl radicals by Fenton chemistry ${ }^{[27,30-33]}$ and the formation of quinone methide metabolites ${ }^{[34]}$ have been proposed as mechanisms of cytotoxicity. It should be noted that other organometallic substituents, such as $\left[\operatorname{Re}(\mathrm{CO})_{3}(\mathrm{Cp})\right],\left[\mathrm{Mn}(\mathrm{CO})_{3}(\mathrm{Cp})\right]$, and $\left[\mathrm{Ru}(\mathrm{Cp})_{2}\right]$, did not lend cytotoxic properties to the $\mathrm{OH}-$ Tam scaffold ${ }^{[35]}$ or phenolic skeleton. ${ }^{[36]}$
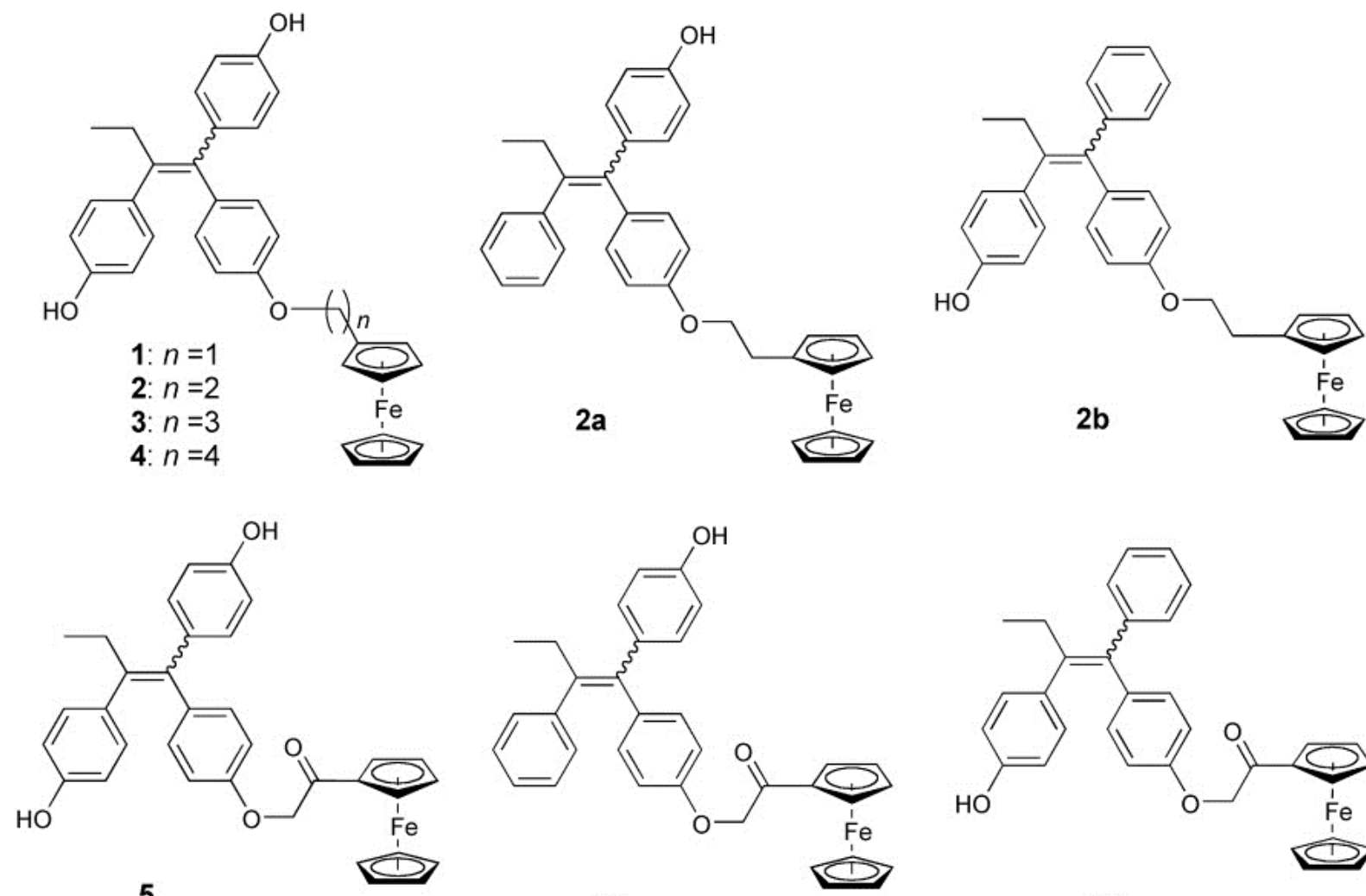

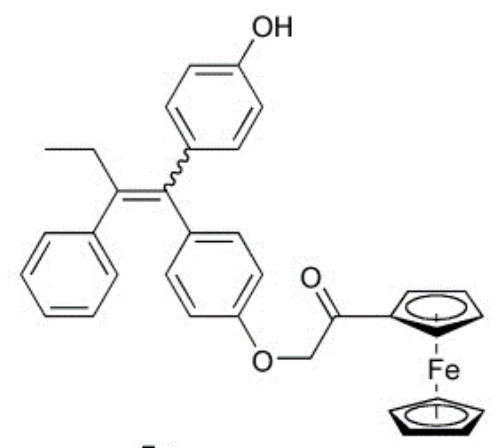

$5 a$

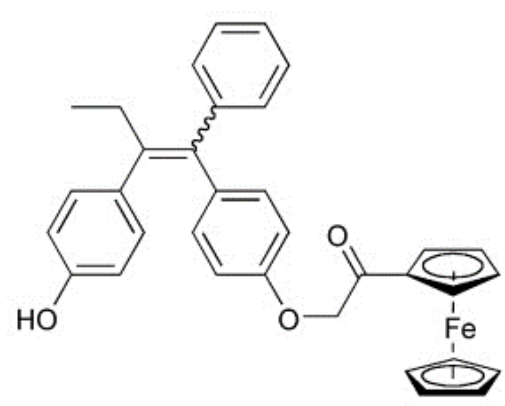

5b 
Recognizing the sensitive nature of the side chain on antiestrogenicity, and the cytotoxicity of some ferrocenyl compounds, we have recently studied the new ferrocenyl triphenylethylene $\mathbf{5}$, which showed promising in vitro results against both ER+ and ER- breast cancer cells. ${ }^{\text {[37-38] }}$ In designing this compound, we chose to functionalize the ferrocenyl group with a ketone, which has been shown to promote double metal-ligand exchange reactions to yield other organometallic compounds, such as those containing ${ }^{188} \mathrm{Re},{ }^{186} \mathrm{Re}$, or ${ }^{99 \mathrm{~m}} \mathrm{Tc} .{ }^{[39,40]}$ Molecular modeling experiments showed that the interaction of $\mathbf{5}$ with the crystal structure of the antiestrogenic conformation of ER $\alpha$ is highly thermodynamically favored, particularly due to the interaction with the ketone and the LBD residue Asp351, ${ }^{[38]}$ and this was subsequently reflected in a high relative binding affinity (RBA) value for ER $\alpha$ of $14 \%$. This good receptor recognition, and the lability of the $\mathrm{CpFe}$ moiety, suggests that this compound could be a useful precursor in the development of ER-targeted radiopharmaceuticals or imaging agents.

We describe here the synthesis, receptor binding properties, proliferative/antiproliferative effects, and electrochemistry of the first series of hydroxytamoxifen-like compounds possessing side chains with organometallic termini. To discover structure-activity relationships (SARs) based on $\mathbf{5}$, we have varied three parameters: the length of the side chain from one to four carbon atoms, the presence of one ( 2 a, $2 \mathbf{b}, 5 \mathbf{a}, \mathbf{5} \mathbf{b})$ or two (1-5) phenolic groups, and the presence $(5,5 \mathrm{a}, \mathbf{5} \mathrm{b})$ or absence $(\mathbf{1}-\mathbf{4}, \mathbf{2} \mathbf{a}, \mathbf{2} \mathbf{b})$ of a ketone group adjacent to the ferrocene.

\section{Results and Discussion}

Synthesis: We generally rely on a synthetic route based on McMurry cross-coupling to obtain the desired alkenes. Reagents 4-hydroxypropiophenone and 4,4'-dihydroxybenzophenone were first transformed into their protected forms, $\mathbf{6}$ and 7, respectively (Scheme 1). Coupling of 6 with 7, by using $\mathrm{TiCl}_{4} / \mathrm{Zn}$ in dry THF, gave 8 as a mixture of $Z$ and $E$ isomers in $67 \%$ yield. Compound 8 reacted with the ferrocenyl alcohols 9-11, by the Mitsunobu reaction, in the presence of triphenylphosphine and DEAD in THF for two days to give 13-16 in 70 to $80 \%$ yield. Deprotection was then performed by saponification of the pivaloate groups with sodium hydroxide in a THF/ $\mathrm{H}_{2} \mathrm{O}$ solution to generate 2-4, as a mixture of $Z$ and $E$ isomers, in 70 to $92 \%$ yield. However, we failed to obtain $1(n=1)$ from saponification. The action of sodium hydroxide on $\mathbf{1 3}$ immediately produced a deep purple color, and the workup yielded a complex mixture of compounds, among which 1,1,2-tris-(4-hydroxyphenyl)but-1-ene was 
identified. Therefore, we used the tert-butyldimethylsilyl protecting group, which allows milder deprotection conditions, and it proved successful (Scheme 1).

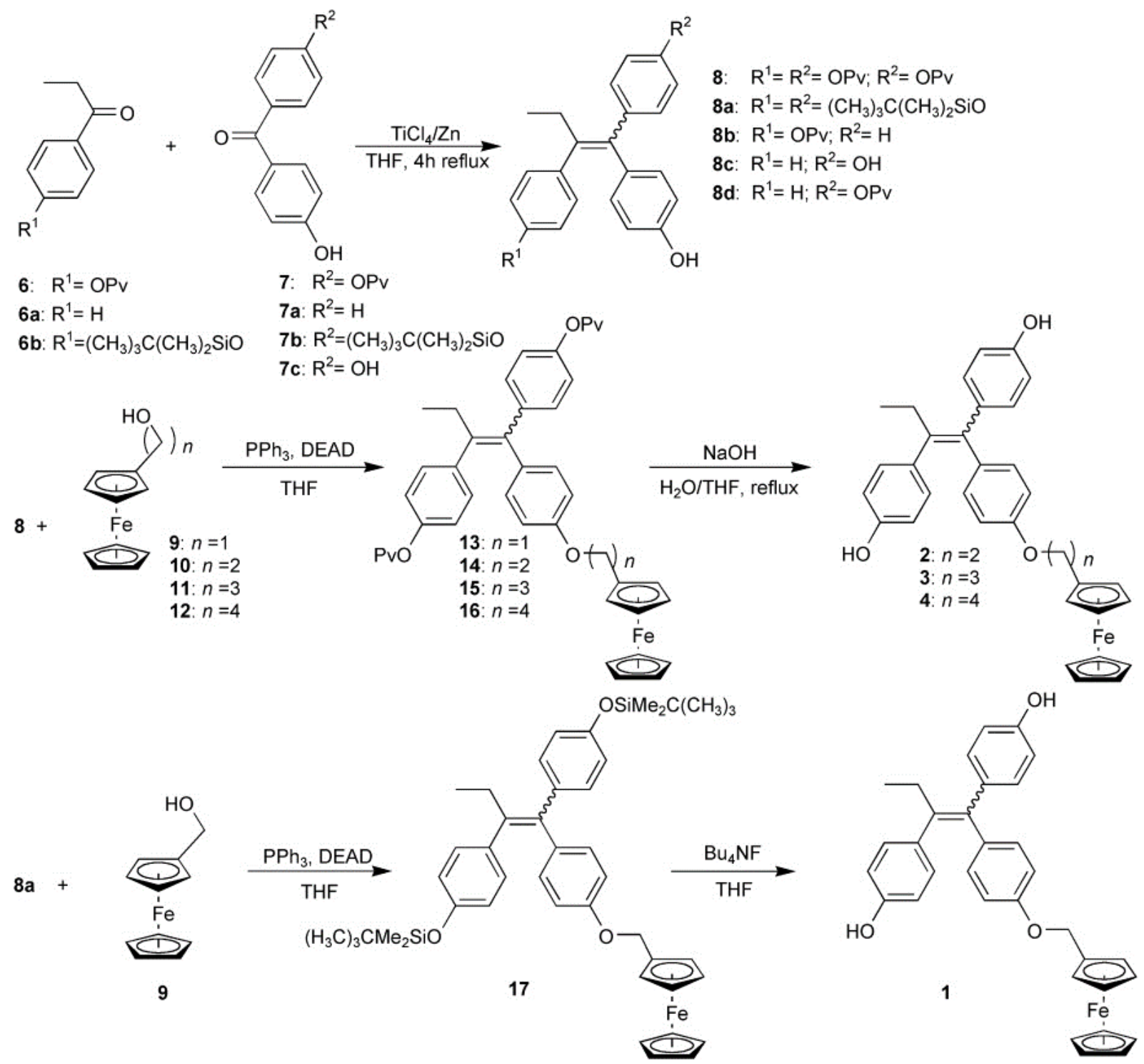

Scheme 1 Synthesis of the ferrocenyl derivatives $\mathbf{1 , 2}, \mathbf{3}$, and $\mathbf{4}$, obtained as a mixture of $Z$ and $E$ isomers.

$\mathrm{DEAD}=$ diethyl azodicarboxylate.

The monophenol $\mathbf{2} \mathbf{b}$ was prepared in the same way as $\mathbf{2}$, but the synthesis started with $\mathbf{6}$ and $\mathbf{7} \mathbf{a}$ to give $\mathbf{8} \mathbf{b}$ (Scheme 1). After alkylation with 10, saponification of the protected ferrocenyl intermediate 18 gave $\mathbf{2} \mathbf{b}$, as a mixture of $Z$ and $E$ isomers, in $79 \%$ yield (Scheme 2). We found that the protection/deprotection steps were important to maximize the yield of the desired product, because when the unprotected phenol $8 \mathbf{c}$ (Scheme 1) reacted directly with 
ferrocenyl ethanol 10, a mixture of monoalkylated $(Z+E)-\mathbf{2}$ a $(31 \%)$ and dialkylated (32\%) was obtained (Scheme 2).

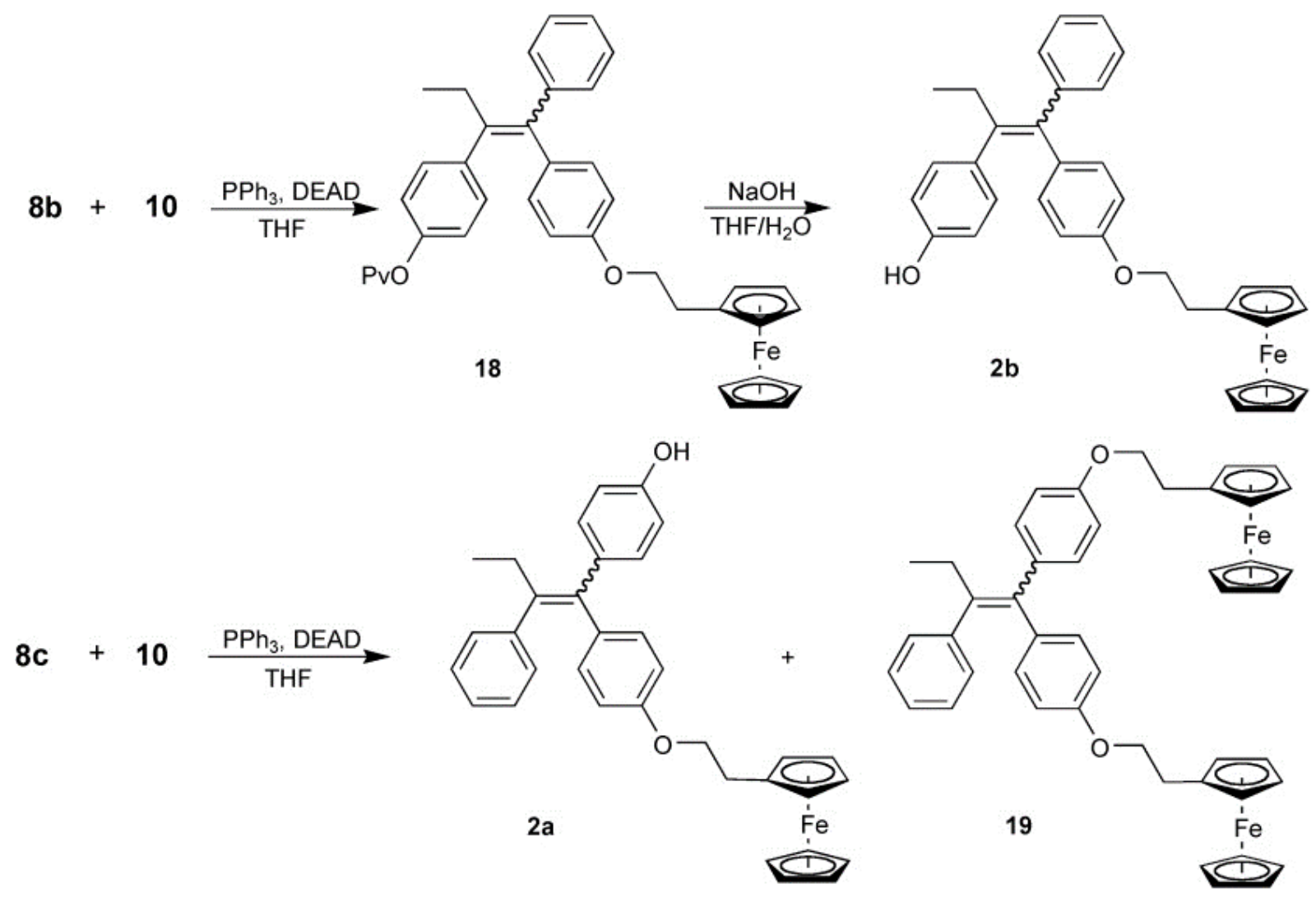

Scheme 2 Synthesis of the ferrocenyl derivatives $\mathbf{2}$ a and $\mathbf{2} \mathbf{b}$ obtained as a mixture of $Z$ and $E$ isomers.

The synthesis of $\mathbf{5}$ has been described. ${ }^{[38]}$ Similarly, addition of $\alpha$-chloroacetylferrocene to the monosodium salts of $\mathbf{8} \mathbf{d}$ and $\mathbf{8} \mathbf{b}$ (Scheme 1), respectively, obtained from the reaction with $\mathrm{NaH}$, produced $20 \mathrm{a}$ and $20 \mathrm{~b}$ (Scheme 3). Refluxing of $20 \mathbf{a}$ and $20 \mathbf{b}$ with $\mathrm{NaOH}$ in $\mathrm{H}_{2} \mathrm{O} / \mathrm{THF}$ for $6 \mathrm{~h}$ gave $(Z+E)-5$ a and $(Z+E)-5 \mathbf{b}$ in $73-75 \%$ yield (Scheme 3 ).

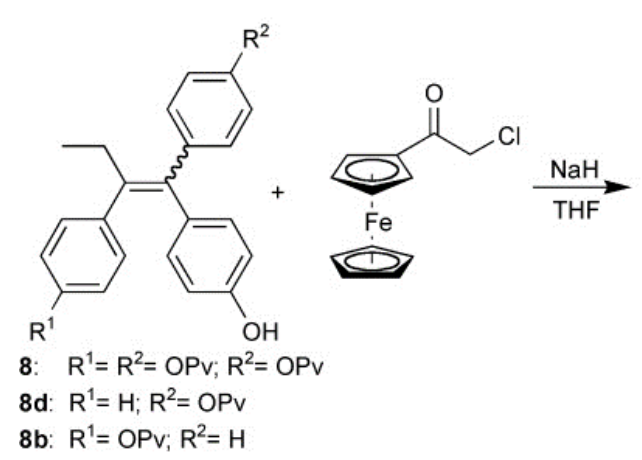

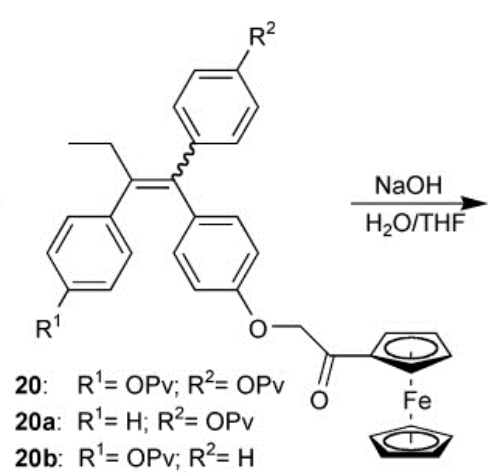

20b: $R^{1}=O P v ; R^{2}=H$

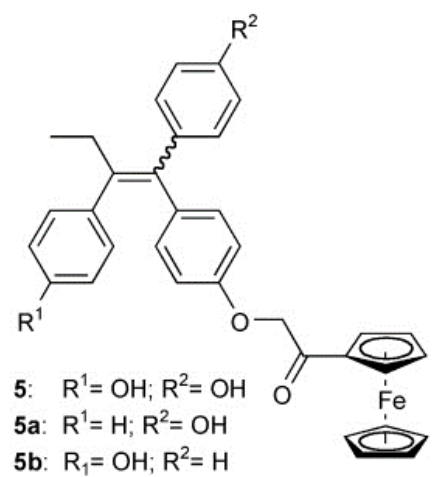


Isomerization: One caveat of the McMurry reaction is that products are usually obtained as mixtures of $Z$ and $E$ isomers. The separation of isomers was achieved with preparative HPLC for 5 and $\mathbf{5} \mathbf{b}$. As previously observed in the hydroxyferrocifen series, ${ }^{[20]}$ the rate of isomerization of $\mathbf{5}$ and $\mathbf{5} \mathbf{b}$ depends strongly on the nature of solvent; they isomerize rapidly in protic solvents, but neither showed isomerization after a week in $\left[\mathrm{D}_{6}\right] \mathrm{DMSO}$ as followed by NMR spectroscopy. Therefore, even though a pure isomer was first introduced, the results from the cell culture tests are very likely the combined activity of the $Z$ and $E$ mixture, but remain pure isomers for the low-temperature receptor binding affinity (RBA) tests. All the compounds of the 1-4 series, including $\mathbf{2}$ a, could be separated by HPLC, but were found to isomerize quite rapidly, roughly within one hour, as followed by NMR spectroscopy in $\mathrm{CDCl}_{3}$. Therefore, we did not separate the isomers preparatively, and all of the biological tests were performed with a mixture. Finally, it was not possible to observe the individual signals of the $Z$ and $E$ isomers of $\mathbf{2} \mathbf{b}$ and $\mathbf{5} \mathbf{a}$ by analytical HPLC, and thus a mixture of isomers was used in all tests.

RBA and molecular-modeling studies on ligand-ER complexation: The affinities of the compounds were determined for ER $\alpha$ and the results are summarized in Table 1. These affinities were not as high as that of OH-Tam, probably due to the greater steric hindrance of the ferrocenyl group as compared to a dimethylamine moiety. In the alkyl series $\mathbf{1 - 4}$, RBA values for ER $\alpha$ decreased as the side chains became longer.

Table 1. RBA values, $\log P o / w$, and effect on the growth of cancer cells of compounds $1-\mathbf{5}$.

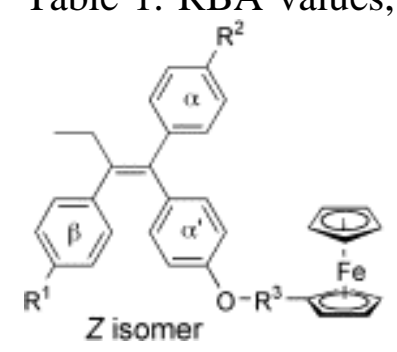

Compound

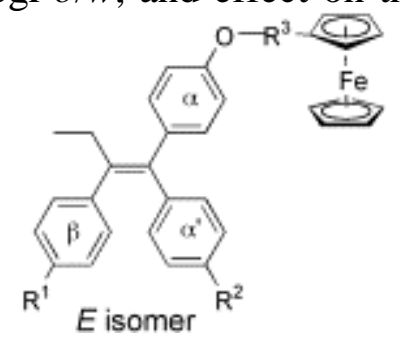

$\mathrm{RBA}$ for
$\operatorname{ER\alpha }[\%]^{[\mathrm{a}]}$
Effect on the growth of cancer cells $[\%]^{[\mathrm{b}]}$ 


\begin{tabular}{|c|c|c|c|c|c|c|c|}
\hline & & & & & & $\begin{array}{l}\text { MCF- } \\
7^{[\mathrm{c}]}\end{array}$ & $\begin{array}{l}\mathbf{P C 3}^{[\mathrm{d}]}\left(\mathrm{IC}_{50}\right. \\
[\mu \mathrm{M}])^{[\mathrm{ee}]}\end{array}$ \\
\hline $17 \beta-E_{2}$ & & & & $100^{[\mathrm{ff}]}$ & 3.5 & $253^{[\mathrm{g}]}$ & - \\
\hline $\begin{array}{l}(Z+E)-\mathrm{OH}- \\
\text { Tam }\end{array}$ & & & & $38.5^{[\mathrm{h}]}$ & $\begin{array}{l}3.2(Z), \\
3.4(E)\end{array}$ & $59^{[i]}$ & - \\
\hline$(Z+E)-\mathbf{1}$ & $\mathrm{OH}$ & $\mathrm{OH}$ & $\mathrm{CH}_{2}$ & $11.9 \pm 0.2$ & $\begin{array}{l}6.7(Z) \\
5.9(E)\end{array}$ & 181 & $65(12 \pm 1)$ \\
\hline$(Z+E)-\mathbf{2}$ & $\mathrm{OH}$ & $\mathrm{OH}$ & $\left(\mathrm{CH}_{2}\right)_{2}$ & $0.9 \pm 0.3$ & $\begin{array}{l}5.7(Z), \\
6.6(E)\end{array}$ & 173 & $48(9.8 \pm 0.1)$ \\
\hline$(Z+E)-\mathbf{3}$ & $\mathrm{OH}$ & $\mathrm{OH}$ & $\left(\mathrm{CH}_{2}\right)_{3}$ & $0.45 \pm 0.05$ & $\begin{array}{l}6.2(Z) \\
7.1(E)\end{array}$ & 118 & $\begin{array}{l}51 \\
(10.2 \pm 0.3)\end{array}$ \\
\hline$(Z+E)-\mathbf{4}$ & $\mathrm{OH}$ & $\mathrm{OH}$ & $\left(\mathrm{CH}_{2}\right)_{4}$ & $0.24 \pm 0.02$ & $\begin{array}{l}6.6(Z) \\
7.5(E)\end{array}$ & 107 & $76(12 \pm 2)$ \\
\hline$(Z+E)-\mathbf{2} \mathbf{a}$ & $\mathrm{H}$ & $\mathrm{OH}$ & $\left(\mathrm{CH}_{2}\right)_{2}$ & $0.16 \pm 0.02$ & $\begin{array}{l}7.9(Z), \\
8.2(E)\end{array}$ & 166 & 90 \\
\hline$(Z+E)-\mathbf{2} \mathbf{b}$ & $\mathrm{OH}$ & $\mathrm{H}$ & $\left(\mathrm{CH}_{2}\right)_{2}$ & $0.13 *$ & 7.9 & 192 & 84 \\
\hline (Z)-5 & $\mathrm{OH}$ & $\mathrm{OH}$ & $\left(\mathrm{CH}_{2}\right)_{2} \mathrm{C}(\mathrm{O})$ & $14 \pm 1^{[\mathrm{j}]}$ & 4.6 & $54^{[k]}$ & $49(7.8 \pm 0.6)$ \\
\hline$(E)-5$ & $\mathrm{OH}$ & $\mathrm{OH}$ & $\left(\mathrm{CH}_{2}\right)_{2} \mathrm{C}(\mathrm{O})$ & $1.19 \pm 0.05^{[\mathrm{j}]}$ & 5.1 & $62^{[k]}$ & $56(8.3 \pm 0.7)$ \\
\hline$(Z+E)-5 \mathbf{a}$ & $\mathrm{H}$ & $\mathrm{OH}$ & $\left(\mathrm{CH}_{2}\right)_{2} \mathrm{C}(\mathrm{O})$ & $4.1 \pm 0.7$ & 5.8 & 108 & 83 \\
\hline$(Z)-5 \mathbf{b}$ & $\mathrm{OH}$ & $\mathrm{H}$ & $\left(\mathrm{CH}_{2}\right)_{2} \mathrm{C}(\mathrm{O})$ & $2.3 \pm 0.4$ & 3.6 & 178 & 102 \\
\hline$(E)-\mathbf{5} \mathbf{b}$ & $\mathrm{OH}$ & $\mathrm{H}$ & $\left(\mathrm{CH}_{2}\right)_{2} \mathrm{C}(\mathrm{O})$ & $4.6 \pm 0.4$ & 5.9 & 164 & 96 \\
\hline
\end{tabular}

[a] Mean of two experiments \pm range, except where an asterisk * appears; values for ER $\beta$ are included in the Supporting Information. [b] Control=cells without added compound, set at $100 \%$ after 5 days of culture in a 
medium without phenol red. [c] Hormone-dependent breast cancer cells, incubation with $1 \mu \mathrm{M}$ except when specified. [d] Hormone-independent prostate cancer cells, incubation with $10 \mu \mathrm{M}$; [e] $\mathrm{IC}_{50}$ values were determined when the percentage of cell growth was lower than $80 \%$, mean of two experiments \pm range; [f] Value by definition. [g] Incubation with $1 \mathrm{nM}$. [h] Value from reference [20]. [i] Value from reference [25]. [j] Value from reference [38]. [k] Incubation with $10 \mu \mathrm{M}$.

Docking experiments for each isomer of $2,2 \mathbf{a}, \mathbf{2} \mathbf{b}, \mathbf{5}, \mathbf{5} \mathbf{a}$, and $5 \mathbf{b}$ in the ligand binding domain (LBD), derived from the structure of ER $\alpha$ crystallized with OH-Tam, showed that the cavity containing the amino side chain is large enough to host the ferrocenyl group, and all molecules lie within the LBD similarly to OH-Tam, with the side chain oriented towards Asp351. Bioligand-receptor stability values are given in Table $\underline{2}$, with more negative values indicating greater stability. The experimental and theoretical results for receptor binding will now be discussed in terms of SARs.

Table 2. Energy variation $(\Delta E)$ values for the binding of the complexes to ER $\alpha$.

\begin{tabular}{|c|c|c|c|}
\hline Compound & $\Delta E\left[\mathrm{kcal} \mathrm{mol}^{-1}\right]$ & Compound & $\Delta E\left[\mathrm{kcal} \mathrm{mol}^{-1}\right]$ \\
\hline (Z)-OH-Tam & -140.6 & & \\
\hline (Z)-5 & -106.9 & $(E)-5$ & -57.1 \\
\hline$(Z)-5 \mathbf{a}$ & -79.2 & $(E)-5 \mathbf{a}$ & -67.6 \\
\hline$(Z)-5 \mathbf{b}$ & -68.2 & $(E)-\mathbf{5} \mathbf{b}$ & -32.2 \\
\hline (Z)-2 & -79.7 & $(E)-\mathbf{2}$ & -38.7 \\
\hline$(Z)-2 \mathbf{a}$ & -69.4 & $(E)-\mathbf{2} \mathbf{a}$ & -61.9 \\
\hline$(Z)-\mathbf{2} \mathbf{b}$ & -58.8 & $(E)-\mathbf{2} \mathbf{b}$ & -28.8 \\
\hline
\end{tabular}


The presence of a carbonyl group on the side chain generally enhanced receptor binding. This is experimentally demonstrated for $(Z)-\mathbf{5} /(Z+E)-\mathbf{2}, \mathbf{5} \mathbf{a} / \mathbf{2} \mathbf{a}$, and $\mathbf{5} \mathbf{b} / \mathbf{2} \mathbf{b}$, and these results are in good agreement with theoretical predictions. This stability seems to arise from hydrogen bonding between the ketone and Asp351. For example, as previously reported, $\Delta E$ found for (Z)-5 was $-89 \mathrm{kcal} \mathrm{mol}^{-1}$ with an interaction between Asp351 and Fe, but the binding became more exothermic $\left(-106 \mathrm{kcal} \mathrm{mol}^{-1}\right)$ when a hydrogen bond between Asp351 and $\mathrm{C}=\mathrm{O}$ was modeled. ${ }^{[38]}$ Figure 1 shows the theoretical hydrogen-bonding interaction between $\mathbf{5} \mathbf{a}$ and Asp351, which is absent for $\mathbf{2}$ a as it lacks the ketone function.
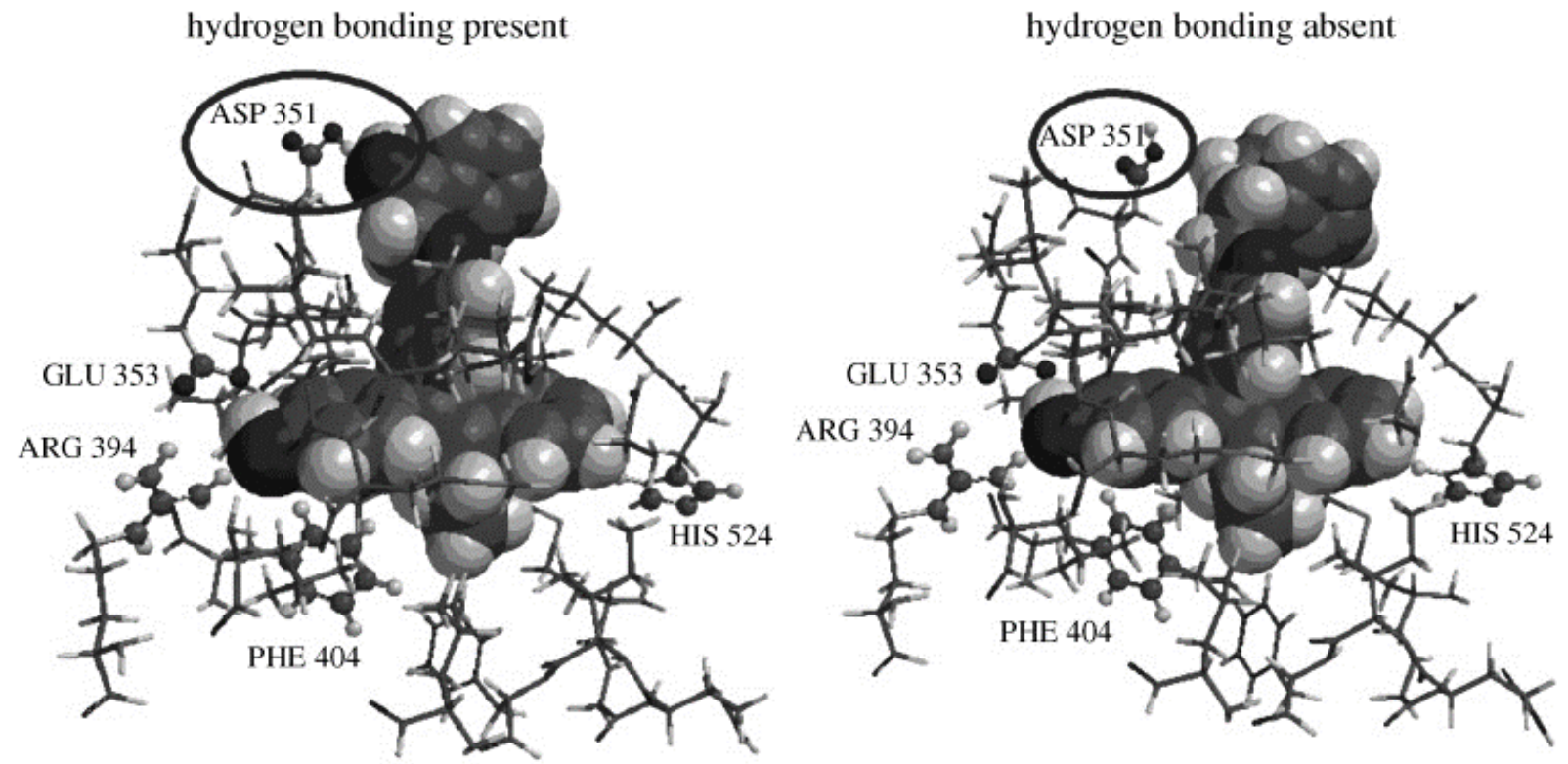

Figure 1 Representation of (Z)-5 a (left) and (Z)-2 a (right) docked in ER $\alpha$, assuming a direct interaction between the ketone group of 5 a and Asp351 (circled).

Depending on the configuration of the bioligand, hydroxyl groups can bind to Glu353, Arg394, and His524, and generally the loss of a hydroxyl group resulted in the loss of theoretical ligand-ER stability. The role of the hydroxyl groups is well illustrated by the striking difference in binding observed for the two isomers of $\mathbf{5}$; the change in configuration from $Z$ to $E$ results in a dramatic drop in the affinity for both receptor isoforms. The $Z$ isomer, which in this case is also the trans isomer, binds more strongly, and this observation is in agreement with previous results with OH-Tam, hydroxyferrocifens, and other triphenylethylenes, in which ER has a preference for the trans over the cis isomer. ${ }^{[10,20,29]}$ Molecular modeling on ER $\alpha$ suggests that (Z)-5 is associated with Asp351 via the ketone, 
with Glu353 and Arg394 via the $\alpha$ phenol, and His524 via the $\beta$ phenol. However, due to the geometry of $(E)-5$, it cannot engage in hydrogen bonding with His524, and the predicted stability is reduced. The situation is similar for $(Z)$ - and $(E)-2$ from a theoretical perspective.

Lipophilicity: Lipophilicity is expressed as the octanol/water partition coefficient, $\log (\mathrm{Po} / \mathrm{w})$, determined by HPLC (Table 1). As expected, the ferrocenyl derivatives yielded higher $\log (P o / w)$ values than $\mathrm{E}_{2}$ and $\mathrm{OH}-\mathrm{Tam}$. What is more unusual, however, is that the $E$ isomers of the compounds are considerably more lipophilic than the corresponding $Z$ isomers. For example, while the difference between $(E)$ - and $(Z)-\mathrm{OH}$-Tam is slight $(\Delta=0.2)$, that of $(E)$ and $(Z)-5 \mathbf{b}$ is significant $(\Delta=2.3)$.

Cell proliferation: The influence of the compounds on the proliferation of cancer cells has been tested on the hormone-dependent MCF-7 breast cancer cells, the hormone-independent MDA-MB-231 breast cancer cells, and the hormone-independent PC-3 prostate cancer cells, and results are given in Table 1 (MDA-MB-231 results are included as Supporting Information).

Compounds 1, 2, 3, and 4 showed an RBA-dependant proliferative effect on MCF-7 cells, which indicated an estrogenic character. Conversely, they had a significant antiproliferative effect on PC-3 cells with $\mathrm{IC}_{50}$ values around $10 \mu \mathrm{M}$, with no correlation between cytotoxicity and chain length. Compounds $\mathbf{2} \mathbf{a}$ and $\mathbf{2} \mathbf{b}$ also had a proliferative effect on MCF-7 cells, but only a modest effect on PC-3 cells. Quite surprisingly none of the complexes showed an antiproliferative effect greater than $20 \%$ inhibition at $10 \mu \mathrm{M}$ for the MBA-MB-231 cells (Supporting Information), whereas the effect on PC-3 is more pronounced. This is the first time that a significant difference has been observed between these two cell lines in our laboratory.

Compounds (Z)- and (E)-5 showed significant and quite similar antiproliferative effects on both MCF-7 and PC-3 cells (Table 1), and they are the only compounds to inhibit the proliferation of both cell lines. To determine whether the antiproliferative effect of 5 on MCF7 cells was a result of ER binding, the cells were incubated with $10 \mu \mathrm{M}$ of 5 in the presence and absence of $1 \mathrm{nM} \mathrm{E} E_{2}$. As shown in Figure 2, the addition of $E_{2}$ did not reverse the antiproliferative effect of $(Z)$ - or $(E)-\mathbf{5}$, which indicated that this effect is cytotoxic and not antiestrogenic. The estrogenic properties of a compound are known to be expressed at low concentrations $\left(10^{-8}-10^{-10} \mathrm{M}\right)$, and we found that $(Z)$ - and $(E)-5$ are indeed strongly 
estrogenic at $10^{-9} \mathrm{M}$ (Figure 2). Thus, the activity of $\mathbf{5}$ on the proliferation of MCF-7 cells seems to be a combination of an estrogenic character and a cytotoxic component; at high concentrations $(>1 \mu \mathrm{M})$, cytotoxicity is dominant, and at low concentrations, the estrogenic effect is more strongly expressed. Thus, despite the bulky side chain, $\mathbf{5}$ acts like the ferrocenyl phenols previously described. ${ }^{[25,29]}$ It should be mentioned that other molecules designed to be antiestrogens in the breast, for example a series of trifluoromethyl-substituted phenylvinyl $\mathrm{E}_{2}$ compounds, exhibited estrogenic properties on MCF-7 cells, regardless of their sterically demanding side group. ${ }^{[41]}$

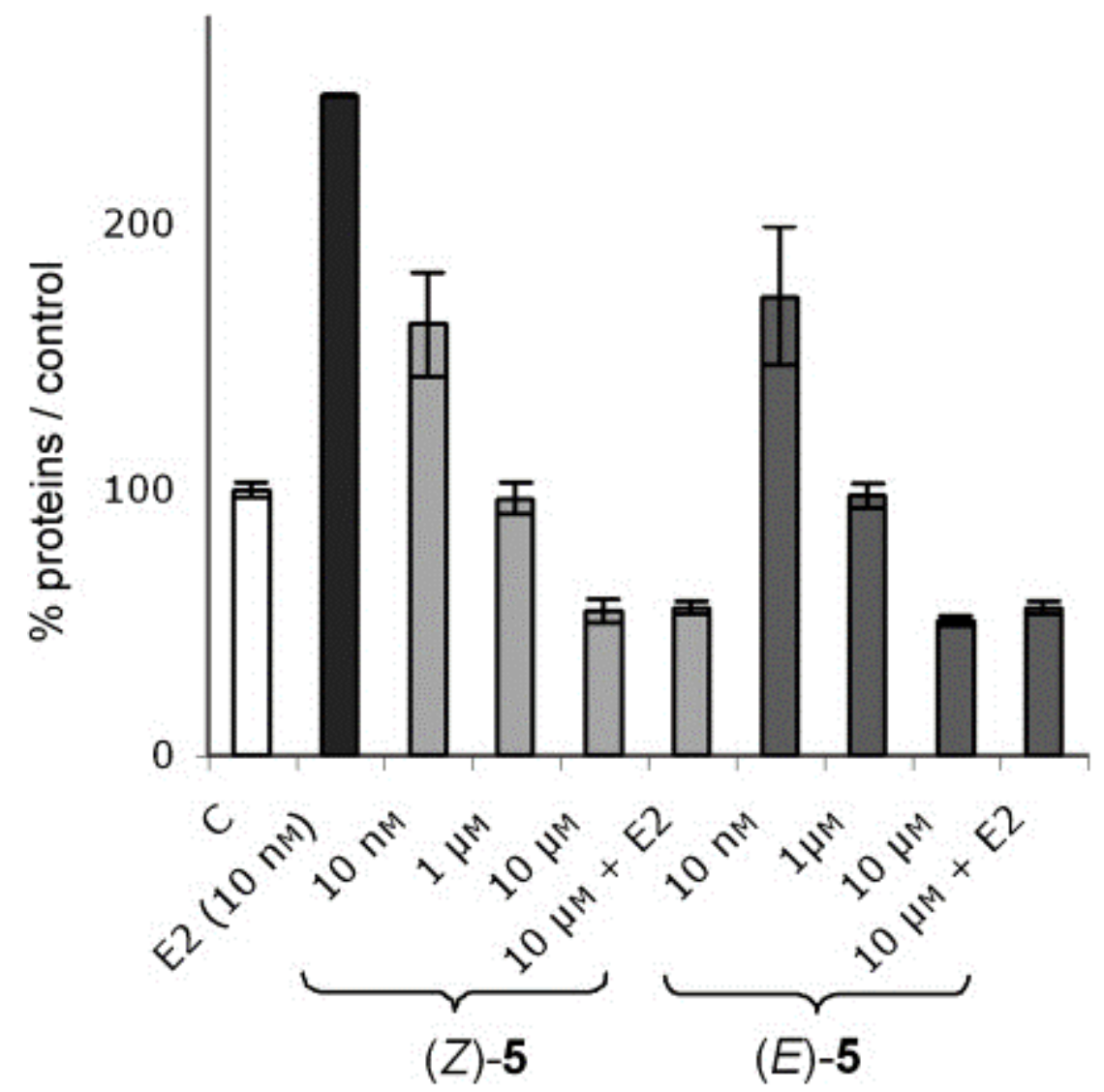

Figure 2 Effect of $\mathrm{E}_{2}$ and of $(Z)$ - and $(E)-5$ on the proliferation of MCF-7 cells (hormone-dependent breast cancer cells) after 5 days of culture. Nontreated MCF-7 cells are used as the control (C) set at $100 \%$. Mean of two separate experiments \pm range.

The ketone and hydroxy functionalities both affect the biological behavior of the studied compounds. The lack of the ketone group seems to increase estrogenicity of the compounds. For example, comparing the antiproliferative activity of $\mathbf{5}$ and $\mathbf{2}$, we observe that they are both cytotoxic on PC-3 cells, and that they have a similar activity on these cells $\left(\mathrm{IC}_{50}\right.$ values 
between 7.8 and $9.8 \mu \mathrm{M}$ ). However, only 5 inhibited the proliferation of the ER+MCF-7 cells, whereas $\mathbf{2}$ had a strongly proliferative effect on those cells. The presence of a second hydroxyl group, on the other hand, markedly increased the compounds' cytotoxicity, and the compounds with only one phenol have no or only a modest antiproliferative effect on PC-3 cells. The importance of the phenol groups has also been observed in the ferrocenyl phenols, in which $\mathrm{Fc}-\mathrm{diOH}$ is more toxic than $\mathrm{Fc}-\mathrm{OH}\left(\mathrm{IC}_{50}=0.6\right.$ and $1.1 \mu \mathrm{M}$, respectively). ${ }^{[22]}$

Electrochemistry: Since it has been suggested that the cytotoxic activity of the ferrocenyl derivatives may originate from their oxidized forms, ${ }^{[27,30-33]}$ the electrochemical behavior of the compounds was examined. At all scan rates, compounds 1-4 gave rise to a reversible $\mathrm{FeCp}_{2}{ }^{0 /+}$ couple and a more positive irreversible phenol oxidation wave. The redox potentials for the $\mathrm{FeCp}_{2}{ }^{0 /+}$ process ranged from 0.432 (3) to $0.506 \mathrm{~V}$ (1) versus SCE, and there was no correlation with the redox potential, the number of carbon atoms in the ferrocenyl chain, or the cytotoxicity of the compounds. Compounds 5, 5a, and $\mathbf{5} \mathbf{b}$ exhibited more complex behavior. At low scan rates, the oxidation of ferrocene was irreversible, although a reduction wave began to appear at higher scan rates. Comparing the CVs of those compounds possessing the carbonyl group, to their alkyl analogues ( $5 \mathbf{a} / \mathbf{2} \mathbf{a}, \mathbf{5} \mathbf{b} / \mathbf{2} \mathbf{b}, \mathbf{5} / \mathbf{2}$; Figure 3), one finds that the ferrocene oxidation waves of the former were higher in intensity and less reversible than those of the latter at low scan rates, but the two waves are similar in intensity and reversibility at high scan rates. This can be interpreted as a slow degradation of radical cation, which yields a product that is oxidized at a less-positive or equal potential to that of the ferrocene moiety. 

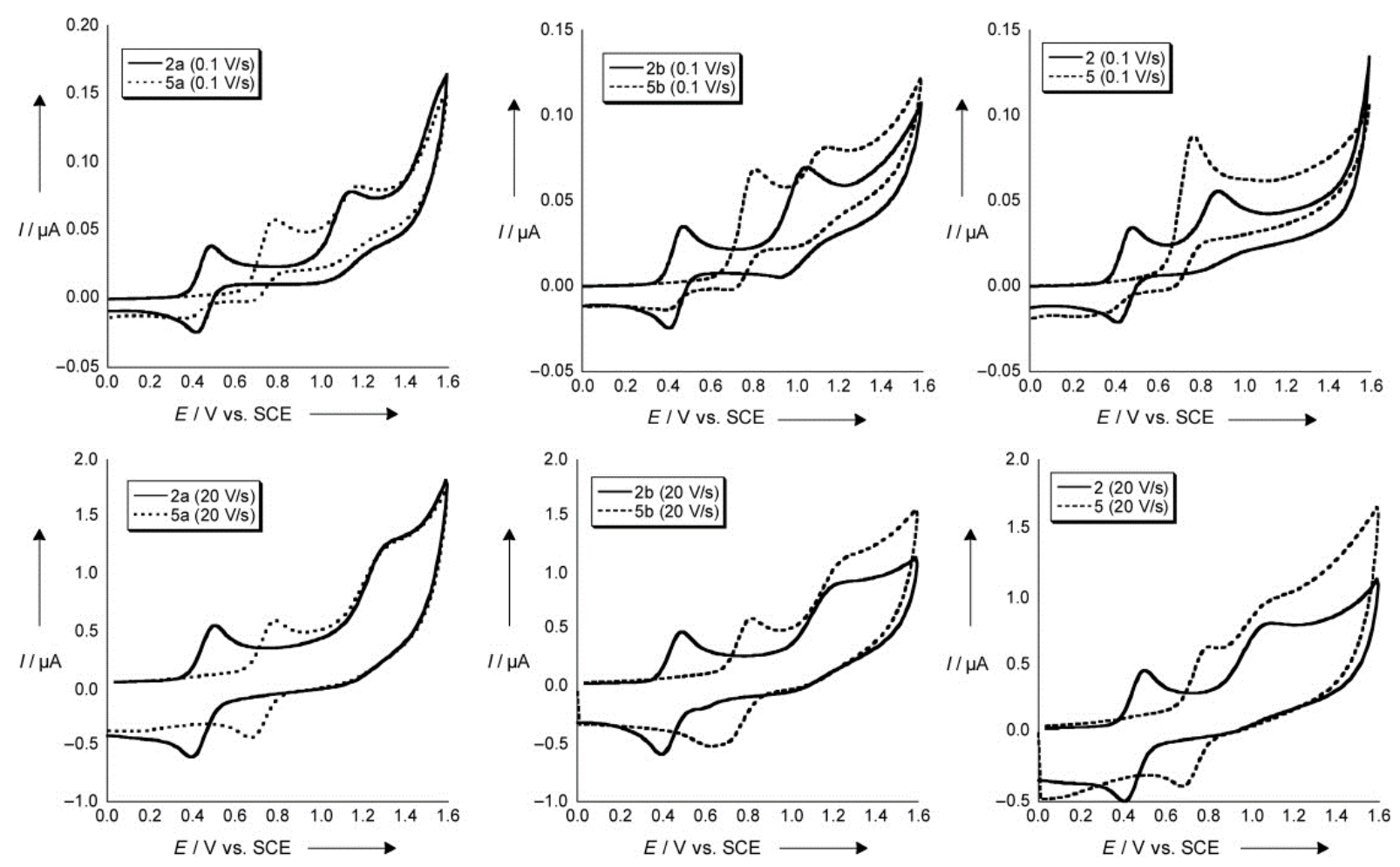

Figure $3 \mathrm{CVs}$ of the alkylFc compounds (-) compared to their acylFc analogues (- - - ) at low $\left(0.1 \mathrm{~V} \mathrm{~s}^{-1}\right)$ and high $\left(20 \mathrm{~V} \mathrm{~s}^{-1}\right)$ scan rates in $\mathrm{DMF} / 0.1 \mathrm{M} \mathrm{Bu}_{4} \mathrm{NBF}_{4}$.

Irreversible phenol oxidation potentials ranged between 0.867 and $1.17 \mathrm{~V}$ (at $0.1 \mathrm{~V} \mathrm{~s}^{-1}$ ) and were bimodal in distribution. The compounds with the least positive phenol oxidation potentials, 1, 2, 3, and $\mathbf{4}$ possess two phenol groups, whereas those with more positive oxidation potentials, $\mathbf{2} \mathbf{a}$ and $\mathbf{2} \mathbf{b}$, have only one. The lowering of the phenol oxidation potential is probably due to the additional resonance stabilization that the second phenol group imparts to the electrochemically generated phenoxy radical. Thus, the presence of two phenol groups gave rise to more accessible phenol oxidation potentials, which correlate with the cytotoxicity of the compounds; this suggests that the generation of active phenoxy radicals or quinones could play a role in the cytotoxicity of these compounds.

\section{Conclusions}

We have described the first series of compounds in which the amino side chain of OH-Tam has been replaced by an organometallic moiety. Although this work was inspired by preliminary molecular-modeling results, which suggested that these compounds should act as strong antiestrogens, all of the compounds gave rise to estrogenic effects. Clearly, a "good fit" 
of the bioligand with the antiestrogenic form of the LBD crystal structure of ER $\alpha$ is not predictive of the antiestrogenic activity of these molecules.

The influence of the side-chain length, phenol groups, and electron-withdrawing ketone group adjacent to the ferrocenyl moiety was studied. In the series of compounds lacking the ketone, a longer ferrocenyl side chain corresponded to lower binding affinities and a lower activity on the proliferation of the MCF-7 cells, although no relationship was observed for cytotoxic effects or electrochemical behavior. The tethering of a ketone function adjacent to the ferrocenyl entity conveyed an additional stabilizing interaction with the ER, accounting, in part, for the good affinity of $\mathbf{5}$ with ER $\alpha$ found experimentally. The ketone group is also responsible for irreversible ferrocene oxidation behavior. Although this group contributed to the stronger cytotoxic activity of $\mathbf{5}$ relative to its analogues, its mere presence is not sufficient. The loss of one hydroxyl group significantly weakens the cytotoxic activity, and indeed, the presence of two phenol groups seems to be the primary factor in the cytotoxicity of these types of compounds.

Therefore, it requires the presence of both the ketone function adjacent to the ferrocene group and the presence of two phenols to yield a cytotoxic molecule, with good binding affinity, and a noteworthy antiproliferative activity. This molecule $\mathbf{5}$ is an interesting prototype for further exploitation, especially for radioimaging and radiotherapy applications as it has been shown that keto-ferrocenyl derivatives can be used as stable precursors of rhenium and technetium derivatives. ${ }^{[39,40]}$

\section{Experimental Section}

General considerations: All air-sensitive reactions were carried out under an argon atmosphere, by using standard Schlenk and vacuum-line techniques. "Standard workup" refers to extraction of the reaction mixture with dichloromethane, washing of the organic phase with water, drying over $\mathrm{MgSO}_{4}$, filtering, removal of the solvent under reduced pressure, and purification by flash chromatography. Dry THF and diethyl ether were obtained by distillation from sodium/benzophenone. Preparative TLC chromatography was performed on silica gel 60 GF254. Flash chromatography was performed on silica gel Merck 60 (0.040$0.060 \mathrm{~mm}$ ), or when necessary on aluminum oxide. HPLC spectra were measured by a Shimadzu instrument. HPLC system: Kromasil C18 columns (analytical: 4.6×250, preparative: $20 \times 250$ ), eluent: water/acetonitrile mixture. IR spectra were obtained on a FTIR 
BOMEM Michelson-100 spectrometer equipped with a DTGS detector. ${ }^{1} \mathrm{H}$ and ${ }^{13} \mathrm{C}$ NMR spectra were recorded on a $300 \mathrm{MHz}$ Bruker spectrometer and the results $\delta$ given in ppm. Mass spectrometry was performed with a Nermag R 10-10C spectrometer. HRMS was carried out with a MStation 700 (JEOL) spectrometer. Elemental analyses were performed by the Microanalysis Service of ICSN (Institut de Chimie des Substances Naturelles), Gif-surYvette. Compounds $6 \mathbf{a}, 7 \mathbf{a}$, and $7 \mathbf{c}$ were purchased from Acros and used as received. The syntheses of compounds Fc-diOH, ${ }^{[20]} \mathbf{5},{ }^{[38]} \mathbf{7},{ }^{[42]} \mathbf{7 b},[43] \mathbf{8} \mathbf{c}^{[25]} \mathbf{8 d},{ }^{[42]} \mathbf{9}, \mathbf{1 0}, \mathbf{1 1}$, and $\mathbf{1 2}{ }^{[44]}$ have been previously described.

\section{Synthesis and characterization}

(p-Trimethylacetoxy)propiophenone (6): Sodium hydride (60\% in oil, $4.8 \mathrm{~g}, 0.12 \mathrm{~mol})$ was slowly added to $p$-hydroxypropiophenone $(15 \mathrm{~g}, 0.1 \mathrm{~mol})$ in dry THF $(200 \mathrm{~mL})$ and the resulting reaction mixture was stirred for $30 \mathrm{~min}$. Trimethylacetyl chloride (14 mL, $0.12 \mathrm{~mol})$ was added and the mixture stirred for a further $2 \mathrm{~h}$. The mixture was poured into water (200 $\mathrm{mL}$ ) and underwent the standard workup to give 6 as a white solid (quant.). M.p. $37{ }^{\circ} \mathrm{C} ;{ }^{1} \mathrm{H}$ NMR (300 MHz, $\mathrm{CDCl}_{3}$ ): $\delta=7.99$ (d, J=8.8 Hz, $2 \mathrm{H} ; \mathrm{CH}_{\text {arom }}$ ), 7.14 (d, J=8.8 Hz, $2 \mathrm{H} ; \mathrm{CH}_{\text {arom }}$ ), 2.96 (q, $\left.J=7.2 \mathrm{~Hz}, 2 \mathrm{H} ; \mathrm{CH}_{2}\right), 1.36\left(\mathrm{~s}, 9 \mathrm{H} ; \mathrm{CH}_{3}\right.$ of $\left.t \mathrm{Bu}\right), 1.22 \mathrm{ppm}\left(\mathrm{t}, J=7.2 \mathrm{~Hz}, 3 \mathrm{H} ; \mathrm{CH}_{3}\right.$ of $\mathrm{Et}) ;{ }^{13} \mathrm{C}$ NMR (75 MHz, $\mathrm{CDCl}_{3}$ ): $\delta=199.6$ (CO), 176.6 (COO), 154.7 (C), 134.3 (C), 129.5 (2 $\left.\mathrm{CH}_{\text {arom }}\right), 121.7\left(2 \mathrm{CH}_{\text {arom }}\right), 39.2(\mathrm{C}, t \mathrm{Bu}), 31.8\left(\mathrm{CH}_{2}\right), 27.0\left(3 \mathrm{CH}_{3}, t \mathrm{Bu}\right), 8.2 \mathrm{ppm}\left(\mathrm{CH}_{3}, \mathrm{Et}\right)$; IR (KBr): $\bar{v}=2987,2929,2872\left(\mathrm{CH}_{2}, \mathrm{CH}_{3}\right), 1750 \mathrm{~cm}^{-1}$ (CO); ESI-MS ( $\left.\mathrm{H}_{2} \mathrm{O} / \mathrm{MeOH} 1: 9\right): \mathrm{m} / z$ : $257.5[M+\mathrm{Na}]^{+}, 289.3[M+\mathrm{Na}+\mathrm{MeOH}]^{+}, 491.7[2 M+\mathrm{Na}]^{+}$; elemental analysis calcd $(\%)$ for $\mathrm{C}_{14} \mathrm{H}_{18} \mathrm{O}_{3}$ : C 71.76, $\mathrm{H}$ 7.74; found: C 71.71, H 7.64.

4-(tert-Butyldimethylsilyloxy)propiophenone (6 b): tert-Butyldimethylchlorosilane (7.54 g, $50 \mathrm{mmol})$ and imidazole $(8.51 \mathrm{~g}, 125 \mathrm{mmol})$ were added to a solution of 4hydroxypropiophenone $(7.51 \mathrm{~g}, 50 \mathrm{mmol})$ in dry DMF $(30 \mathrm{~mL})$, and the reaction mixture was stirred for $3 \mathrm{~h}$. The solution was poured into a $5 \%$ solution of $\mathrm{NaHCO}_{3}(200 \mathrm{~mL})$ and underwent the standard workup to give $\mathbf{1 7}$ as a colorless oil. Another synthesis of $\mathbf{6} \mathbf{b}$ has been published and the characterization of $\mathbf{6} \mathbf{b}$ was identical to that reported. ${ }^{[45]}$ 
1-(4-Hydroxyphenyl)-1,2-bis(4-trimethyacetoxyphenyl)but-1-ene (8): $\mathrm{TiCl}_{4}(5.3 \mathrm{~mL}, 48$ mmol) was added dropwise under an inert atmosphere to a suspension of $\mathrm{Zn}(5.36 \mathrm{~g}, 82$ $\mathrm{mmol})$ in dry THF $(100 \mathrm{~mL})$. After the $\mathrm{Zn} / \mathrm{TiCl}_{4}$ suspension had been refluxed for $2 \mathrm{~h}, 6$ (2.3 $\mathrm{g}, 10 \mathrm{mmol})$ and 7 (3.58 g, $12 \mathrm{mmol})$ dissolved in dry THF (50 mL) were added. The mixture was heated at reflux for $2 \mathrm{~h}$. After cooling, the mixture was hydrolyzed by acidified water (200 mL), followed by the standard workup. The crude product was recrystallized in ethanol, yielding 8 as a white powder (3.36 g, $67 \%$; isomer ratio: 1:5). Major isomer: ${ }^{1} \mathrm{H}$ NMR (300 $\mathrm{MHz}, \mathrm{CDCl}_{3}$ ): $\delta=7.22$ (d, J=8.6 Hz, $2 \mathrm{H} ; \mathrm{CH}_{\text {arom }}$ ), 7.09 (d, J=8.6 Hz, $2 \mathrm{H} ; \mathrm{CH}_{\text {arom }}$ ), 7.05 (d, $\left.J=8.6 \mathrm{~Hz}, 2 \mathrm{H} ; \mathrm{CH}_{\text {arom }}\right), 6.87$ (d, J=8.6 Hz, $\left.2 \mathrm{H} ; \mathrm{CH}_{\text {arom }}\right), 6.71$ (d, J=8.6 Hz, $2 \mathrm{H} ; \mathrm{CH}_{\text {arom }}$ ), 6.47 (d, J=8.6 Hz, $2 \mathrm{H} ; \mathrm{CH}_{\text {arom }}$ ), 2.45 (q, J=7.3 Hz, $\left.2 \mathrm{H} ; \mathrm{CH}_{2}\right), 1.37$ (s, $9 \mathrm{H} ; \mathrm{CH}_{3}$ of $\left.t \mathrm{Bu}\right), 1.34$ (s, $9 \mathrm{H} ; \mathrm{CH}_{3}$ of $\left.t \mathrm{Bu}\right), 0.91 \mathrm{ppm}\left(\mathrm{t}, J=7.3 \mathrm{~Hz}, 3 \mathrm{H} ; \mathrm{CH}_{3}\right.$ of $\left.\mathrm{Et}\right) ;{ }^{13} \mathrm{C} \mathrm{NMR}\left(75 \mathrm{MHz}, \mathrm{CDCl}_{3}\right)$ : $\delta=177.3$ (CO), 153.8 (C), 149.7 (C), 149.2 (C), 141.0 (C), 140.8 (C), 139.7 (C), 137.8 (C), $135.1(\mathrm{C}), 132.1$ (2 $\left.\mathrm{CH}_{\text {arom }}\right), 130.5\left(2 \mathrm{CH}_{\text {arom }}\right), 130.4\left(2 \mathrm{CH}_{\text {arom }}\right), 121.1\left(2 \mathrm{CH}_{\text {arom }}\right), 120.9$ (2 $\left.\mathrm{CH}_{\text {arom }}\right), 114.5\left(2 \mathrm{CH}_{\text {arom }}\right), 39.0(2 \mathrm{C}, t \mathrm{Bu}), 28.9\left(\mathrm{CH}_{2}\right), 27.1\left(2 \times 3 \mathrm{CH}_{3}, t \mathrm{Bu}\right), 13.5 \mathrm{ppm}$ $\left(\mathrm{CH}_{3}, \mathrm{Et}\right)$; IR $(\mathrm{KBr}): \bar{v}=3407(\mathrm{O}-\mathrm{H}), 2977\left(\mathrm{C}-\mathrm{H}_{\text {arom }}\right), 1749,1726(\mathrm{CO}), 1610(\mathrm{C}=\mathrm{C}), 1504$ $\mathrm{cm}^{-1}\left(\mathrm{C}=\mathrm{C}\right.$ arom); MS (EI): $\mathrm{m} / \mathrm{z}: 500\left[\mathrm{M}^{+}, 57[t \mathrm{Bu}]^{+}\right.$; HRMS (EI, $\left.70 \mathrm{eV}\right): \mathrm{m} / \mathrm{z}:$ calcd for $\mathrm{C}_{32} \mathrm{H}_{36} \mathrm{O}_{5}: 500.2563[M]^{+}$; found: 500.2574 .

1,2-Bis[4-(tert-butyl-dimethylsilyloxy)phenyl]-1-(4-hydroxyphenyl)but-1-ene (8 a): The same procedure as that of 8 was used with $\mathbf{6} \mathbf{b}(2.64 \mathrm{~g}, 10 \mathrm{mmol})$ and $7 \mathbf{b}(3.28 \mathrm{~g}, 10 \mathrm{mmol})$. After standard workup, the crude product was chromatographed on a silica-gel column with dichloromethane as the eluent to yield pure 8 a as an oil (75\%; isomer ratio: 1:1). ${ }^{1} \mathrm{H}$ NMR (300 MHz, $\mathrm{CDCl}_{3}$ ): $\delta=7.09,7.08\left(\mathrm{~d}, J=8.5 \mathrm{~Hz}, 2 \mathrm{H} ; \mathrm{CH}_{\text {arom }}\right), 6.95$ and 6.94 (d, J=8.6 Hz, $2 \mathrm{H}$; $\mathrm{CH}_{\text {arom}}$ ), 6.81 and $6.79\left(\mathrm{~d}, J=8.5 \mathrm{~Hz}, 2 \mathrm{H} ; \mathrm{CH}_{\text {arom }}\right), 6.75-6.60\left(\mathrm{~m}, 4 \mathrm{H} ; \mathrm{CH}_{\text {arom }}\right), 5.13,4.84$ (s, $1 \mathrm{H} ; \mathrm{OH}), 2.45$ (q, J=7.3 Hz, 2 H; $\mathrm{CH}_{2}$ ), 1.01, 0.97 (s, $\left.9 \mathrm{H} ; t \mathrm{BuSi}\right), 0.99$ (t, J=7.3 Hz, $3 \mathrm{H}$; $\mathrm{CH}_{3}$ ), 0.97, 0.94 (s, $\left.9 \mathrm{H} ; t \mathrm{BuSi}\right), 0.48,0.45$ (d, J=8.6 Hz, $\left.2 \mathrm{H} ; \mathrm{CH}_{\text {arom }}\right), 0.23,0.17$ (s, $6 \mathrm{H}$; $\mathrm{SiMe}_{2}$ ), 0.17, $0.12 \mathrm{ppm}\left(\mathrm{s}, 6 \mathrm{H} ; \mathrm{SiMe}_{2}\right.$ ); ${ }^{13} \mathrm{C} \mathrm{NMR}\left(75 \mathrm{MHz}, \mathrm{CDCl}_{3}\right.$ ): $\delta=154.2$ (C), 153.7 (C), 153.4, 153.3 (C), 140.7 (C), 137.4 (C), 137.0, 136.6 (C), 136.5, 136.2 (C), 135.6, 135.5 (C), $132.1,131.9\left(2 \mathrm{CH}_{\text {arom }}\right), 130.8,130.7\left(2 \mathrm{CH}_{\text {arom }}\right), 130.7,130.6\left(2 \mathrm{CH}_{\text {arom }}\right), 119.6,119.5$ (2 $\left.\mathrm{CH}_{\text {arom }}\right), 119.5,118.8\left(2 \mathrm{CH}_{\text {arom }}\right), 114.9,114.2\left(2 \mathrm{CH}_{\text {arom }}\right), 28.9,28.8\left(\mathrm{CH}_{2}\right), 25.7(2 t \mathrm{Bu})$, $18.2(2 \mathrm{C}, t \mathrm{BuSi}), 13.7\left(\mathrm{CH}_{3}\right),-4.4 \mathrm{ppm}\left(2 \mathrm{SiMe}_{2}\right)$; IR $(\mathrm{KBr}): \bar{v}=3428(\mathrm{OH}), 1260 \mathrm{~cm}^{-1}$

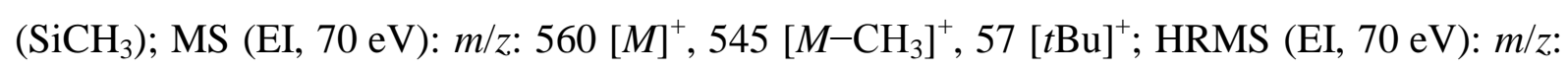
calcd for $\mathrm{C}_{34} \mathrm{H}_{48} \mathrm{O}_{3} \mathrm{Si}_{2}: 560.3142[M]^{+}$; found: 560.3132 . 
1-(4-Hydroxyphenyl)-1-(4-trimethylacetoxyphenyl)-2-phenylbut-1-ene (8 b): The same procedure as that of 8 was used with 4-hydroxybenzophenone $(4 \mathrm{~g}, 20 \mathrm{mmol})$ and $\mathbf{6}(4.69 \mathrm{~g}$, $20 \mathrm{mmol})$ to give $\mathbf{8} \mathbf{b}(70 \%$; isomer ratio: $1: 1)$. ${ }^{1} \mathrm{H} \mathrm{NMR}\left(300 \mathrm{MHz}, \mathrm{CDCl}_{3}\right): \delta=7.30-6.46(\mathrm{~m}$, $13 \mathrm{H} ; \mathrm{CH}_{\text {arom}}$ ), 4.99, 4.74 (s, $\left.1 \mathrm{H} ; \mathrm{OH}\right), 2.40,2.38$ (q, J=7.4 Hz, $2 \mathrm{H} ; \mathrm{CH}_{2}$ ), 1.34, 1.33 (s, $9 \mathrm{H}$; $\mathrm{CH}_{3}$ of $\left.t \mathrm{Bu}\right), 0.86,0.85 \mathrm{ppm}\left(\mathrm{t}, J=7.4 \mathrm{~Hz}, 3 \mathrm{H} ; \mathrm{CH}_{3}\right.$ of $\left.\mathrm{Et}\right) ;{ }^{13} \mathrm{C} \mathrm{NMR}\left(75 \mathrm{MHz}, \mathrm{CDCl}_{3}\right)$ : $\delta=177.2$ (CO), 154.4, 153.6 (C), 149.2 (C), 143.6, 143.1 (C), 141.0, 140.5 (C), 139.8, 139.7 (C), 138.7, 138.6 (C), 136.0, 135.4 (C), 132.1, 130.8 (2 $\left.\mathrm{CH}_{\text {arom }}\right), 130.7,130.6\left(2 \mathrm{CH}_{\text {arom }}\right)$, 129.4, $128.1\left(2 \mathrm{CH}_{\text {arom }}\right), 127.4,126.6\left(2 \mathrm{CH}_{\text {arom }}\right), 125.8,125.6\left(\mathrm{CH}_{\text {arom }}\right), 120.9,120.8$ (2 $\left.\mathrm{CH}_{\text {arom }}\right), 115.0,114.4\left(2 \mathrm{CH}_{\text {arom }}\right), 39.1(\mathrm{Cq}, t \mathrm{Bu}), 28.9\left(\mathrm{CH}_{2}\right), 27.1\left(\mathrm{CH}_{3}, t \mathrm{Bu}\right), 13.6 \mathrm{ppm}$ $\left(\mathrm{CH}_{3}, \mathrm{Et}\right) ; \mathrm{MS}(\mathrm{EI}): \mathrm{m} / z: 400[M]^{+}, 57[t \mathrm{Bu}]^{+}$; elemental analysis calcd $(\%)$ for $\mathrm{C}_{27} \mathrm{H}_{28} \mathrm{O}_{3}: \mathrm{C}$ 80.90, H 6.99; found: C 80.77, H 6.96.

General procedure for the preparation of $13,14,15$, and 16: A solution of DEAD $(0.42 \mathrm{~g}$, $2.4 \mathrm{mmol})$ in dry THF $(3 \mathrm{~mL})$ was added dropwise at $0{ }^{\circ} \mathrm{C}$ to a solution of ferrocenyl alcohol 9, 10, 11, or 12 (2.4 mmol), respectively. Compound $\mathbf{8}(1 \mathrm{~g}, 2 \mathrm{mmol})$ and triphenylphosphine $(0.74 \mathrm{~g}, 2.8 \mathrm{mmol})$ in dry THF $(12 \mathrm{~mL})$ were then added. The reaction was stirred at room temperature for $48 \mathrm{~h}$. The solvent was evaporated under vacuum and the residue was purified by aluminum oxide column chromatography (petroleum ether) to give 13, 14, 15, or 16 (isomer ratio: 1:1) as yellow solids. These compounds were recrystallized from ether/pentane.

1-[4-(Ferrocenylmethoxy)phenyl]-1,2-bis[4-(trimethylacetoxy)phenyl]but-1-ene (13): The reaction was accomplished with $0.519 \mathrm{~g}(2.4 \mathrm{mmol})$ of ferrocenylmethanol 9. Yield: $83 \%$; ${ }^{1} \mathrm{H}$ NMR (300 MHz, $\mathrm{CDCl}_{3}$ ): $\delta=7.25-6.50\left(\mathrm{~m}, 12 \mathrm{H} ; \mathrm{CH}_{\mathrm{arom}}\right), 4.81,4.67$ (s, $\left.2 \mathrm{H} ; \mathrm{OCH}_{2}\right), 4.34$, $4.26\left(\mathrm{t}, J=1.8 \mathrm{~Hz}, 2 \mathrm{H} ; \mathrm{C}_{5} \mathrm{H}_{4}\right), 4.21,4.16\left(\mathrm{t}, J=1.8 \mathrm{~Hz}, 2 \mathrm{H} ; \mathrm{C}_{5} \mathrm{H}_{4}\right), 4.20,4.15$ (s, $\left.5 \mathrm{H} ; \mathrm{Cp}\right), 2.46$ (q, J=7.4 Hz, $\left.2 \mathrm{H} ; \mathrm{CH}_{2}\right), 1.37,1.35,1.34,1.30(\mathrm{~s}, 18 \mathrm{H} ; 2$ t $\mathrm{Bu}), 0.92 \mathrm{ppm}(\mathrm{t}, J=7.4 \mathrm{~Hz}, 3 \mathrm{H}$; $\left.\mathrm{CH}_{3}\right) ;{ }^{13} \mathrm{C}$ NMR (75 MHz, $\mathrm{CDCl}_{3}$ ): $\delta=177.1$ (CO), 177.0 (CO), 157.8, 157.0 (C), 149.8, 149.3 (C), 149.3, 149.0 (C), 141.2, 141.1 (C), 140.7, 140.5 (C), 139.7, 139.5 (C), 137.9, 137.8 (C), 135.8, 135.1 (C), 131.9, $131.7\left(2 \mathrm{CH}_{\text {arom }}\right), 130.5,130.4\left(2 \times 2 \mathrm{CH}_{\text {arom }}\right), 121.1,120.9\left(2 \mathrm{CH}_{\text {arom }}\right)$, 120.9, $120.4\left(2 \mathrm{CH}_{\text {arom }}\right), 114.3,113.8\left(2 \mathrm{CH}_{\text {arom }}\right), 82.6\left(\mathrm{C}, \mathrm{C}_{5} \mathrm{H}_{4}\right), 69.2\left(2 \mathrm{CH}, \mathrm{C}_{5} \mathrm{H}_{4}\right), 68.6$ $\left(2 \mathrm{CH}, \mathrm{C}_{5} \mathrm{H}_{4}\right), 68.5(5 \mathrm{CH}, \mathrm{Cp}), 66.6,66.3\left(\mathrm{OCH}_{2}\right), 39.1(\mathrm{C}, t \mathrm{Bu}), 39.0(\mathrm{C}, t \mathrm{Bu}), 29.1,29.0$ $\left(\mathrm{CH}_{2}\right), 27.1\left(6 \mathrm{CH}_{3}, t \mathrm{Bu}\right), 13.5 \mathrm{ppm}\left(\mathrm{CH}_{3}\right)$; IR $(\mathrm{KBr}): \bar{v}=1752 \mathrm{~cm}^{-1}(\mathrm{CO})$; MS (EI): $m / z: 698$ 
$[M]^{+}, 199\left[\mathrm{CpFe}\left(\eta^{5}-\mathrm{C}_{5} \mathrm{H}_{4}\right) \mathrm{CH}_{2}\right]^{+}$; elemental analysis calcd (\%) for $\mathrm{C}_{43} \mathrm{H}_{46} \mathrm{FeO}_{5}: \mathrm{C} 73.92, \mathrm{H}$ 6.63; found: C 73.58, H 6.66 .

1-[4-(2-Ferrocenylethoxy)phenyl]-1,2-bis(4-trimethylacetoxyphenyl)but-1-ene (14): The reaction was accomplished with ferrocenylethanol $10(0.552 \mathrm{~g}, 2.4 \mathrm{mmol})$. Yield $85 \%$; ${ }^{1} \mathrm{H}$ NMR (300 MHz, $\left.\mathrm{CDCl}_{3}\right): \delta=7.20-6.65\left(\mathrm{~m}, 10 \mathrm{H} ; \mathrm{CH}_{\text {arom}}\right), 6.66,6.49$ (d, J=8.8 Hz, $2 \mathrm{H}$; $\mathrm{CH}_{\text {arom }}$ ), 4.20-3.90 (m, $\left.9 \mathrm{H} ; \mathrm{CpFeC}_{5} \mathrm{H}_{4}\right), 4.01,3.89$ (t, J=7.0 Hz, $2 \mathrm{H} ; \mathrm{OCH}_{2}$ ), 2.76, 2.66 (t, $\left.J=7.0 \mathrm{~Hz}, 2 \mathrm{H} ; \mathrm{CH}_{2}\right), 2.41,2.38\left(\mathrm{q}, J=7.4 \mathrm{~Hz}, 2 \mathrm{H} ; \mathrm{CH}_{2}\right), 1.29,1.26,1.25,1.22(\mathrm{~s}, 18 \mathrm{H}$; $2 t \mathrm{Bu}), 0.86,0.84 \mathrm{ppm}\left(\mathrm{t}, J=7.4 \mathrm{~Hz}, 3 \mathrm{H} ; \mathrm{CH}_{3}\right) ;{ }^{13} \mathrm{C} \mathrm{NMR}\left(75 \mathrm{MHz}, \mathrm{CDCl}_{3}\right): \delta=177.0(\mathrm{CO})$, 157.7, 156.9 (C), 149.7, 149.3 (C), 149.2, 149.0 (C), 141.2, 141.1 (C), 140.7, 140.5 (C), 139.6, 139.5 (C), 137.9, 137.8 (C), 135.7, 135.0 (C), 132.0, $131.7\left(2 \mathrm{CH}_{\text {arom }}\right), 130.6,130.5$ (2 $\left.\mathrm{CH}_{\text {arom }}\right), 130.5,130.4\left(2 \mathrm{CH}_{\text {arom }}\right), 121.1,121.0\left(2 \mathrm{CH}_{\text {arom }}\right), 120.9,120.4\left(2 \mathrm{CH}_{\text {arom }}\right), 114.1$, $113.5\left(2 \mathrm{CH}_{\text {arom }}\right), 84.8\left(\mathrm{C}, \mathrm{C}_{5} \mathrm{H}_{4}\right), 68.6\left(5 \mathrm{CH}, \mathrm{Cp}+2 \mathrm{CH}, \mathrm{C}_{5} \mathrm{H}_{4}\right), 68.4,68.2\left(\mathrm{OCH}_{2}\right), 67.5,67.4$ $\left(2 \mathrm{CH}, \mathrm{C}_{5} \mathrm{H}_{4}\right), 39.0(2 \mathrm{C}, t \mathrm{Bu}), 29.5,29.0\left(\mathrm{CH}_{2}\right), 27.1\left(2 \times 3 \mathrm{CH}_{3}, t \mathrm{Bu}\right), 13.6 \mathrm{ppm}\left(\mathrm{CH}_{3}\right)$; IR $(\mathrm{KBr}): \bar{v}=1752 \mathrm{~cm}^{-1}(\mathrm{CO})$; MS $\left(\mathrm{CI}, \mathrm{NH}_{3}\right): m / z: 712[M+\mathrm{H}]^{+}, 730\left[M+\mathrm{NH}_{4}\right]^{+}$; elemental analysis calcd (\%) for $\mathrm{C}_{44} \mathrm{H}_{48} \mathrm{FeO}_{5}$ : C 74.15, H 6.78; found: C 74.03, H 6.84.

1-[4-(3-Ferrocenylpropoxy)phenyl]-1,2-bis(4-trimethylacetoxyphenyl)but-1-ene (15): The reaction was accomplished with ferrocenylpropanol 11 (0.586 g, $2.4 \mathrm{mmol})$. Yield: $70 \%$; ${ }^{1} \mathrm{H}$ NMR $\left(300 \mathrm{MHz}, \mathrm{CDCl}_{3}\right): \delta=7.24-6.74\left(\mathrm{~m}, 10 \mathrm{H} ; \mathrm{CH}_{\text {arom }}\right), 6.73,6.57(\mathrm{~d}, J=8.8 \mathrm{~Hz}, 2 \mathrm{H}$; $\mathrm{CH}_{\text {arom }}$ ), 4.14-4.02 (m, $\left.9 \mathrm{H} ; \mathrm{CpFeC}_{5} \mathrm{H}_{4}\right), 3.99,3.86$ (t, J=6.3 Hz, $\left.2 \mathrm{H} ; \mathrm{OCH}_{2}\right), 2.59-2.39$ (m, $\left.4 \mathrm{H} ; 2 \mathrm{CH}_{2}\right), 2.09-1.86\left(\mathrm{~m}, 2 \mathrm{H} ; \mathrm{CH}_{2}\right), 1.37,1.34$ (s, $\left.9 \mathrm{H} ; t \mathrm{Bu}\right), 1.34,1.30(\mathrm{~s}, 9 \mathrm{H} ; t \mathrm{Bu}), 0.91$, $0.90 \mathrm{ppm}\left(\mathrm{t}, J=7.4 \mathrm{~Hz}, 3 \mathrm{H} ; \mathrm{CH}_{3}\right) ;{ }^{13} \mathrm{C} \mathrm{NMR}\left(75 \mathrm{MHz}, \mathrm{CDCl}_{3}\right): \delta=176.2$ (2CO), 157.1, 156.2 (C), 152.5, 148.8 (C), 151.6, 148.4 (C), 140.2 (C), 139.8 (C), 138.7 (C), 136.9 (C), 134.1 (C), 131.1, 130.9 (2 $\left.\mathrm{CH}_{\text {arom }}\right), 129.6$ (2 $\left.\mathrm{CH}_{\text {arom }}\right), 129.5$ (2 $\left.\mathrm{CH}_{\text {arom }}\right), 120.2,119.5\left(2 \mathrm{CH}_{\text {arom }}\right), 120.0$ $\left(2 \mathrm{CH}_{\text {arom }}\right), 113.2,112.6\left(2 \mathrm{CH}_{\text {arom }}\right), 87.4\left(\mathrm{C}, \mathrm{C}_{5} \mathrm{H}_{4}\right), 67.6(5 \mathrm{CH}, \mathrm{Cp}), 67.2\left(2 \mathrm{CH}, \mathrm{C}_{5} \mathrm{H}_{4}\right), 66.4$, $66.3\left(2 \mathrm{CH}, \mathrm{C}_{5} \mathrm{H}_{4}\right), 66.2\left(\mathrm{OCH}_{2}\right), 38.2(2 \mathrm{C}, t \mathrm{Bu}), 29.6\left(\mathrm{CH}_{2}\right), 28.8,28.1\left(\mathrm{CH}_{2}\right), 26.3$ $\left(2 \times 3 \mathrm{CH}_{3}, t \mathrm{Bu}\right), 25.0\left(\mathrm{CH}_{2}\right), 12.7 \mathrm{ppm}\left(\mathrm{CH}_{3}\right)$; IR $(\mathrm{KBr}): \bar{v}=1752 \mathrm{~cm}^{-1}(\mathrm{CO}) ; \mathrm{MS}(\mathrm{EI}): m / z$ : $726[M]^{+}, 661[M-\mathrm{Cp}]^{+}, 199\left[\mathrm{CpFe}\left(\eta^{5}-\mathrm{C}_{5} \mathrm{H}_{4}\right) \mathrm{CH}_{2}\right]^{+}, 121[\mathrm{CpFe}]^{+}, 57[t \mathrm{Bu}]^{+}$; elemental analysis calcd (\%) for $\mathrm{C}_{45} \mathrm{H}_{50} \mathrm{FeO}_{5}$ : C 74.37, H 6.93; found: C 74.28, H 6.99. 
1-[4-(4-Ferrocenylbutoxy)phenyl]-1,2-bis(4-trimethylacetoxyphenyl)but-1-ene (16): The reaction was accomplished with ferrocenylbutanol $12(0.620 \mathrm{~g}, 2.4 \mathrm{mmol})$. Yield: $74 \%$; ${ }^{1} \mathrm{H}$ NMR (300 MHz, $\mathrm{CDCl}_{3}$ ): $\delta=7.30-6.50\left(\mathrm{~m}, 12 \mathrm{H} ; \mathrm{CH}_{\text {arom}}\right), 4.12,4.09$ (s, $\left.5 \mathrm{H} ; \mathrm{Cp}\right), 4.06,4.05$ (s, $2 \mathrm{H} ; \mathrm{C}_{5} \mathrm{H}_{4}$ ), 4.04, 4.03 (s, $2 \mathrm{H} ; \mathrm{C}_{5} \mathrm{H}_{4}$ ), 3.99, 3.85 (t, J=6.2 Hz, $2 \mathrm{H} ; \mathrm{OCH}_{2}$ ), 2.55-2.30 (m, $4 \mathrm{H} ; 2 \mathrm{CH}_{2}$ ), 1.90-1.52 (m, $\left.4 \mathrm{H} ; \mathrm{CH}_{2}-\mathrm{CH}_{2}\right), 1.38,1.35,1.30,1.27$ (s, $\left.18 \mathrm{H} ; 2 t \mathrm{Bu}\right), 0.94,0.92$ ppm (t, $\left.J=7 \mathrm{~Hz}, 3 \mathrm{H} ; \mathrm{CH}_{3}\right) ;{ }^{13} \mathrm{C}$ NMR $\left(75 \mathrm{MHz}, \mathrm{CDCl}_{3}\right): \delta=177.2,177.1,177.0,176.9$ (2 CO), 157.2, 155.0 (C), 149.7 (C), 149.2 (C), 141.1 (C), 140.6, 140.5 (C), 139.6 (C), 137.9, 137.8 (C), 135.6, 134.9 (C), 132.0, $131.7\left(2 \mathrm{CH}_{\text {arom }}\right), 130.5\left(2 \mathrm{CH}_{\text {arom }}\right), 130.5,130.4\left(2 \mathrm{CH}_{\text {arom }}\right)$, 121.1, 120.9 (2 $\left.\mathrm{CH}_{\text {arom }}\right), 120.9,120.4\left(2 \mathrm{CH}_{\text {arom }}\right), 114.0,113.4\left(2 \mathrm{CH}_{\text {arom }}\right), 89.0\left(\mathrm{C}, \mathrm{C}_{5} \mathrm{H}_{4}\right), 68.5$ $(5 \mathrm{CH}, \mathrm{Cp}), 68.1\left(2 \mathrm{CH}, \mathrm{C}_{5} \mathrm{H}_{4}\right), 67.7,67.4\left(\mathrm{OCH}_{2}\right), 67.1\left(2 \mathrm{CH}, \mathrm{C}_{5} \mathrm{H}_{4}\right), 39.1(\mathrm{C}, t \mathrm{Bu}), 39.0(\mathrm{C}$, $t \mathrm{Bu}), 29.7,29.0\left(\mathrm{CH}_{2}\right), 29.3\left(\mathrm{CH}_{2}\right), 29.2\left(\mathrm{CH}_{2}\right), 27.5\left(\mathrm{CH}_{2}\right), 27.2\left(2 \times 3 \mathrm{CH}_{3}, t \mathrm{Bu}\right), 13.6 \mathrm{ppm}$ $\left(\mathrm{CH}_{3}\right)$; IR (KBr): $\bar{v}=1754 \mathrm{~cm}^{-1}(\mathrm{CO})$; MS (EI): $m / z: 740[M]^{+}, 199\left[\mathrm{CpFe}\left(\eta^{5}-\mathrm{C}_{5} \mathrm{H}_{4}\right) \mathrm{CH}_{2}\right]^{+}$, $121[\mathrm{CpFe}]^{+}$; elemental analysis calcd (\%) for $\mathrm{C}_{46} \mathrm{H}_{52} \mathrm{FeO}_{5}$ : C 74.58, $\mathrm{H}$ 7.07; found: C 74.51, H 7.36 .

1-[4-(2-Ferrocenylethoxy)phenyl]-1-phenyl-2-(4-trimethylacetoxyphenyl)but-1-ene (18):

The same procedure as that for $\mathbf{1 3}$ was used to synthesize 18, except that the substituted butene 8 was replaced by 8 b $(0.801 \mathrm{~g}, 2 \mathrm{mmol})$. Yield: $96 \%$; isomer ratio: 55:45; ${ }^{1} \mathrm{H}$ NMR (300 MHz, $\left.\mathrm{CDCl}_{3}\right): \delta=7.40-6.75\left(\mathrm{~m}, 11 \mathrm{H} ; \mathrm{CH}_{\text {arom }}\right), 6.87$ and $6.58\left(\mathrm{~d}, J=8.5 \mathrm{~Hz}, 2 \mathrm{H} ; \mathrm{CH}_{\text {arom }}\right.$ ), 4.25-4.00 (m, $9 \mathrm{H} ; \mathrm{CpFeC}_{5} \mathrm{H}_{4}$ ), 4.11, 3.97 (t, J=7.0 Hz, $2 \mathrm{H} ; \mathrm{OCH}_{2}$ ), 2.85, 2.75 (t, J=7.0 Hz, $2 \mathrm{H} ; \mathrm{CH}_{2}$ ), 2.51, 2.45 (q, J=7.4 Hz, $\left.2 \mathrm{H} ; \mathrm{CH}_{2}\right), 1.35,1.34$ (s, $\left.9 \mathrm{H} ; t \mathrm{Bu}\right), 0.96,0.94$ ppm (t, $\left.J=7.4 \mathrm{~Hz}, 3 \mathrm{H} ; \mathrm{CH}_{3}\right) ;{ }^{13} \mathrm{C} \mathrm{NMR}\left(75 \mathrm{MHz}, \mathrm{CDCl}_{3}\right): \delta=177.0(\mathrm{CO}), 157.7,156.9(\mathrm{C}), 149.2(\mathrm{C})$, 143.7, 143.2 (C), 141.0, 140.4 (C), 139.7 (C), 138.8, 138.7 (C), 135.7, 135.0 (C), 131.9, 130.8 (2 $\left.\mathrm{CH}_{\text {arom }}\right), 130.6\left(2 \mathrm{CH}_{\text {arom }}\right), 130.6,129.4\left(2 \mathrm{CH}_{\text {arom }}\right), 128.1,127.4\left(2 \mathrm{CH}_{\text {arom }}\right), 126.6,125.8$ $\left(\mathrm{CH}_{\text {arom }}\right), 120.9,120.8\left(2 \mathrm{CH}_{\text {arom }}\right), 114.1,113.5\left(2 \mathrm{CH}_{\text {arom }}\right), 84.7\left(\mathrm{C}, \mathrm{C}_{5} \mathrm{H}_{4}\right), 68.5(5 \mathrm{CH}$, $\left.\mathrm{Cp}+2 \mathrm{CH}, \mathrm{C}_{5} \mathrm{H}_{4}\right), 68.4,68.2\left(\mathrm{OCH}_{2}\right), 67.5,67.4\left(2 \mathrm{CH}, \mathrm{C}_{5} \mathrm{H}_{4}\right), 39.0(\mathrm{C}, t \mathrm{Bu}), 29.6,29.5\left(\mathrm{CH}_{2}\right)$, $29.0\left(\mathrm{CH}_{2}\right), 27.1\left(3 \mathrm{CH}_{3}, t \mathrm{Bu}\right), 13.6 \mathrm{ppm}\left(\mathrm{CH}_{3}\right)$; IR $(\mathrm{KBr}): \bar{v}=1756,1747 \mathrm{~cm}^{-1}(\mathrm{CO})$; MS (CI, $\left.\mathrm{NH}_{3}\right): m / z: 612[M+\mathrm{H}]^{+}, 630\left[M+\mathrm{NH}_{4}\right]^{+}$; elemental analysis calcd $(\%)$ for $\mathrm{C}_{39} \mathrm{H}_{40} \mathrm{FeO}_{3}: \mathrm{C}$ 76.46, H 6.58; found: C 76.56, H 6.61.

General procedure for the preparation of $\mathbf{2 , 3 , 4}$, and $\mathbf{2}$ b: Sodium hydroxide $(0.80 \mathrm{~g}, 20$ mmol) was added to a solution of $\mathbf{1 4}, \mathbf{1 5}, \mathbf{1 6}$, and 18 (2 mmol), respectively, dissolved in THF $(30 \mathrm{~mL})$ and water $(40 \mathrm{~mL})$. The reaction mixture was heated under reflux for $24 \mathrm{~h}$. The 
solution was hydrolyzed, acidified to $\mathrm{pH} 1$, and underwent the standard workup. The residue was purified on an aluminum oxide column (eluent: dichloromethane/acetone 95:5). The products were further purified by preparative HPLC with a solution of acetonitrile and water or pure acetonitrile. The isomers (distinctly separate on TLC plates, eluent: dichloromethane, in an approximately 1:1 ratio) could be easily separated but re-isomerized rapidly, before the solvents could be removed. Recrystallization failed to occur because the solutions became oily at low temperature, and at room temperature the compounds degraded in a few days.

1-[4-(2-Ferrocenylethoxy)phenyl]-1,2-bis(4-hydroxyphenyl)but-1-ene (2): The reaction was accomplished with $\mathbf{1 4}(1.425 \mathrm{~g}, 2 \mathrm{mmol})$. The product was purified by preparative HPLC with acetonitrile/water 90:10 as the eluent. Compound $\mathbf{2}$ was retrieved as a yellow solid (92\%). ${ }^{1} \mathrm{H}$ NMR (300 MHz, $\left.\mathrm{CDCl}_{3}\right): \delta=7.11,7.05$ (d, J=8.6 Hz, $2 \mathrm{H} ; \mathrm{CH}_{\text {arom }}$ ), 6.94 (d, J=8.6 $\mathrm{Hz}, 2 \mathrm{H} ; \mathrm{CH}_{\text {arom }}$ ), 6.85, 6.76 (d, J=8.6 Hz, $\left.2 \mathrm{H} ; \mathrm{CH}_{\text {arom }}\right), 6.75,6.70$ (d, J=8.6 Hz, $2 \mathrm{H} ; \mathrm{CH}_{\text {arom }}$ ), 6.60, 6.59 (d, J=8.6 Hz, $\left.2 \mathrm{H} ; \mathrm{CH}_{\text {arom }}\right), 6.53,6.45$ (d, J=8.6 Hz, $2 \mathrm{H} ; \mathrm{CH}_{\text {arom }}$ ), 4.25-4.02 (m, $9 \mathrm{H} ; \mathrm{CpFeC}_{5} \mathrm{H}_{4}$ ), 4.08, 3.93 (t, J=7.0 Hz, $2 \mathrm{H} ; \mathrm{OCH}_{2}$ ), 2.80, 2.69 (t, J=7.0 Hz, $2 \mathrm{H} ; \mathrm{CH}_{2}$ ), 2.42 (q, J=7.3 Hz, $\left.2 \mathrm{H} ; \mathrm{CH}_{2}\right), 0.90 \mathrm{ppm}\left(\mathrm{t}, J=7.3 \mathrm{~Hz}, 3 \mathrm{H} ; \mathrm{CH}_{3}\right) ;{ }^{13} \mathrm{C} \mathrm{NMR}\left(75 \mathrm{MHz}, \mathrm{CDCl}_{3}\right)$ : $\delta=158.8,158.0$ (C), 155.8, 154.9 (C), 155.3 (C), 141.9 (C), 138.7 (C), 138.0, 137.8 (C), 137.6, 137.4 (C), 136.1 (C), 133.5, $133.4\left(2 \mathrm{CH}_{\text {arom }}\right), 132.3\left(2 \mathrm{CH}_{\text {arom }}\right), 132.2,132.0\left(2 \mathrm{CH}_{\text {arom }}\right)$, 116.4, $115.8\left(2 \mathrm{CH}_{\text {arom }}\right), 116.3\left(2 \mathrm{CH}_{\text {arom }}\right), 115.5,114.8\left(2 \mathrm{CH}_{\text {arom }}\right), 86.3\left(\mathrm{C}, \mathrm{C}_{5} \mathrm{H}_{4}\right), 70.2$ $\left(5 \mathrm{CH}, \mathrm{Cp}+2 \mathrm{CH}, \mathrm{C}_{5} \mathrm{H}_{4}\right), 69.9,69.7\left(\mathrm{OCH}_{2}\right), 69.1,69.0\left(2 \mathrm{CH}, \mathrm{C}_{5} \mathrm{H}_{4}\right), 31.0,30.9\left(\mathrm{CH}_{2}\right), 30.3$ $\left(\mathrm{CH}_{2}\right), 15.1 \mathrm{ppm}\left(\mathrm{CH}_{3}\right)$; IR $(\mathrm{KBr}): \bar{v}=3417(\mathrm{OH}), 2869,2928,2962 \mathrm{~cm}^{-1}\left(\mathrm{CH}_{2}, \mathrm{CH}_{3}\right)$; HRMS $\left(\mathrm{CI}, \mathrm{CH}_{4}\right): \mathrm{m} / z$ : calcd for $\mathrm{C}_{34} \mathrm{H}_{33} \mathrm{FeO}_{3}: 545.1780[M+\mathrm{H}]^{+}$; found: 545.1786.

\section{1-[4-(2-Ferrocenylethoxy)phenyl]-1-phenyl-2-(4-hydroxyphenyl)but-1-ene $\quad(2$ b): The} reaction was accomplished with $18(1.225 \mathrm{~g}, 2 \mathrm{mmol})$. The product was purified by preparative HPLC with pure acetonitrile. Compound $\mathbf{2} \mathbf{b}$ was retrieved as a yellow solid (79\%). ${ }^{1} \mathrm{H}$ NMR $\left(300 \mathrm{MHz}, \mathrm{CDCl}_{3}\right): \delta=7.35-6.75\left(\mathrm{~m}, 9 \mathrm{H} ; \mathrm{CH}_{\text {arom }}\right), 6.75-6.42(\mathrm{~m}, 4 \mathrm{H}$; $\mathrm{CH}_{\text {arom }}$ ), 4.56, 4.54 (s, $\left.1 \mathrm{H} ; \mathrm{OH}\right), 4.15-3.95$ (m, $\left.9 \mathrm{H} ; \mathrm{C}_{5} \mathrm{H}_{4} \mathrm{FeCp}\right), 4.04,3.89$ (t, J=7.0 Hz, $2 \mathrm{H}$; $\mathrm{OCH}_{2}$ ), 2.76, 2.66 (t, J=7.0 Hz, 2 H; $\mathrm{CH}_{2}$ ), 2.37, 2.36 (q, J=7.4 Hz, $2 \mathrm{H} ; \mathrm{CH}_{2}$ ), 0.87, 0.85 ppm (t, J=7.4 Hz, $\left.3 \mathrm{H} ; \mathrm{CH}_{3}\right) ;{ }^{13} \mathrm{C} \mathrm{NMR}\left(75 \mathrm{MHz}, \mathrm{CDCl}_{3}\right): \delta=157.5,156.7$ (C), 153.7 (C), 144.0, 143.6 (C), 141.3, 140.7 (C), 138.0, 137.9 (C), 136.2, 135.7 (C), 134.8 (C), 131.9, 130.9 (2 $\left.\mathrm{CH}_{\text {arom }}\right), 130.9,130.8\left(2 \mathrm{CH}_{\text {arom }}\right), 130.6,129.5\left(2 \mathrm{CH}_{\text {arom }}\right), 128.1,127.3\left(2 \mathrm{CH}_{\text {arom }}\right), 126.4$, $125.5(\mathrm{CH}), 114.9,114.8\left(2 \mathrm{CH}_{\text {arom }}\right), 114.0,113.4\left(2 \mathrm{CH}_{\text {arom }}\right), 84.8\left(\mathrm{C}, \mathrm{C}_{5} \mathrm{H}_{4}\right), 68.6(5 \mathrm{CH}$, 
$\left.\mathrm{Cp}+2 \mathrm{CH}, \mathrm{C}_{5} \mathrm{H}_{4}\right), 68.5,68.3\left(\mathrm{OCH}_{2}\right), 67.5,67.4\left(2 \mathrm{CH}, \mathrm{C}_{5} \mathrm{H}_{4}\right), 29.6,29.5\left(\mathrm{CH}_{2}\right), 28.9\left(\mathrm{CH}_{2}\right)$, $13.6 \mathrm{ppm}\left(\mathrm{CH}_{3}\right)$; IR $(\mathrm{KBr}): v=3432 \mathrm{~cm}^{-1}(\mathrm{OH})$; HRMS $\left(\mathrm{CI}, \mathrm{CH}_{4}\right): \mathrm{m} / z$ : calcd for $\mathrm{C}_{34} \mathrm{H}_{33} \mathrm{FeO}_{2}$ : $529.1830[M+\mathrm{H}]^{+}$; found: 529.1829 .

1-[4-(3-Ferrocenylpropoxy)phenyl]-1,2-bis(4-hydroxyphenyl)but-1-ene (3): The reaction was accomplished with 15 (1.453 g, $2 \mathrm{mmol})$. The product was purified by preparative HPLC with acetonitrile/water 90:10 as the eluent. Compound $\mathbf{3}$ was retrieved as a yellow solid (70\%). ${ }^{1} \mathrm{H}$ NMR $\left(300 \mathrm{MHz}, \mathrm{CDCl}_{3}\right): \delta=7.11,7.06$ (d, J=8.7 Hz, $2 \mathrm{H} ; \mathrm{CH}_{\text {arom }}$ ), 6.94 (d, $J=8.7$ $\mathrm{Hz}, 4 \mathrm{H} ; \mathrm{CH}_{\text {arom }}$ ), 6.86, 6.76 (d, J=8.7 Hz, $2 \mathrm{H} ; \mathrm{CH}_{\text {arom }}$ ), 6.75, 6.71 (d, J=8.7 Hz, $2 \mathrm{H} ; \mathrm{CH}_{\text {arom }}$ ), 6.60 (d, J=8.7 Hz, $2 \mathrm{H}$; $\mathrm{CH}_{\text {arom }}$ ), 6.55, 6.45 (d, J=8.7 Hz, $2 \mathrm{H} ; \mathrm{CH}_{\text {arom }}$ ), 4.14-4.01 (m, $9 \mathrm{H}$; $\mathrm{CpFeC}_{5} \mathrm{H}_{4}$ ), 3.97, 3.85 (t, J=6.3 Hz, $\left.2 \mathrm{H} ; \mathrm{OCH}_{2}\right), 2.55-2.36\left(\mathrm{~m}, 4 \mathrm{H} ; 2 \mathrm{CH}_{2}\right), 2.06-1.75$ (m, $\left.2 \mathrm{H} ; \mathrm{CH}_{2}\right), 0.91,0.90 \mathrm{ppm}\left(\mathrm{t}, J=7.3 \mathrm{~Hz}, 3 \mathrm{H} ; \mathrm{CH}_{3}\right) ;{ }^{13} \mathrm{C} \mathrm{NMR}\left(75 \mathrm{MHz}, \mathrm{CDCl}_{3}\right): \delta=157.6$, 156.7 (C), 154.2, 153.3 (C), 153.7 (C), 140.5 (C), 137.3 (C), 136.6, 136.4 (C), 136.2, 136.0 (C), 134.9 (C), 132.2, $132.0\left(2 \mathrm{CH}_{\text {arom }}\right), 130.9\left(2 \mathrm{CH}_{\text {arom }}\right), 130.8,130.6\left(2 \mathrm{CH}_{\text {arom }}\right), 115.0$, $114.3\left(2 \mathrm{CH}_{\text {arom }}\right), 114.8$ (2 $\left.\mathrm{CH}_{\text {arom }}\right), 114.1,113.4\left(2 \mathrm{CH}_{\text {arom }}\right), 88.6,88.4\left(\mathrm{C}, \mathrm{C}_{5} \mathrm{H}_{4}\right), 68.7,68.6$ (5 CH, Cp), $68.2\left(2 \mathrm{CH}, \mathrm{C}_{5} \mathrm{H}_{4}\right), 67.4,67.2\left(\mathrm{OCH}_{2}\right), 67.3\left(2 \mathrm{CH}, \mathrm{C}_{5} \mathrm{H}_{4}\right), 30.6,30.4\left(\mathrm{CH}_{2}\right), 28.9$ $\left(\mathrm{CH}_{2}\right)$, 26.0, $25.9\left(\mathrm{CH}_{2}\right), 13.7 \mathrm{ppm}\left(\mathrm{CH}_{3}\right)$; IR $(\mathrm{KBr}): \bar{v}=3407 \mathrm{~cm}^{-1}(\mathrm{OH})$; HRMS $\left(\mathrm{CI}, \mathrm{CH}_{4}\right)$ : $m / z:$ calcd for $\mathrm{C}_{35} \mathrm{H}_{35} \mathrm{FeO}_{5}[M+\mathrm{H}]^{+}$: 559.1936; found: 559.1926 .

1-[4-(4-Ferrocenylbutoxy)phenyl]-1,2-bis(4-hydroxyphenyl)but-1-ene (4): The reaction was accomplished with $\mathbf{1 6}(1.481 \mathrm{~g}, 2 \mathrm{mmol})$. The product was purified by preparative HPLC with acetonitrile/water 90:10 as the eluent. Compound $\mathbf{4}$ was retrieved as a yellow solid (83\%). ${ }^{1} \mathrm{H}$ NMR (300 MHz, $\left.\mathrm{CDCl}_{3}\right): \delta=7.13,7.08$ (d, J=8.7 Hz, $2 \mathrm{H} ; \mathrm{CH}_{\text {arom }}$ ), 6.96 (d, J=8.7 $\mathrm{Hz}, 2 \mathrm{H} ; \mathrm{CH}_{\text {arom }}$ ), 6.87, 6.79 (d, J=8.7 Hz, $\left.2 \mathrm{H} ; \mathrm{CH}_{\text {arom }}\right), 6.77,6.73$ (d, J=8.7 Hz, $2 \mathrm{H} ; \mathrm{CH}_{\text {arom }}$ ), 6.63, 6.61 (d, J=8.7 Hz, $2 \mathrm{H} ; \mathrm{CH}_{\text {arom }}$ ), 6.61, 6.60 (d, J=8.7 Hz, $2 \mathrm{H} ; \mathrm{CH}_{\text {arom }}$ ), 6.56, 6.48 (d, $J=8.7 \mathrm{~Hz}, 2 \mathrm{H} ; \mathrm{CH}_{\text {arom}}$ ), 4.19-4.03 (m, $\left.9 \mathrm{H} ; \mathrm{CpFeC}_{5} \mathrm{H}_{4}\right), 3.99,3.85$ (t, J=6.3 Hz, $2 \mathrm{H} ; \mathrm{OCH}_{2}$ ), 2.52-2.30 (m, $4 \mathrm{H} ; 2 \mathrm{CH}_{2}$ ), 1.93-1.54 (m, $4 \mathrm{H} ; \mathrm{CH}_{2}-\mathrm{CH}_{2}$ ), 0.93 ppm (t, J=7.3 Hz, $3 \mathrm{H} ; \mathrm{CH}_{3}$ ); ${ }^{13} \mathrm{C}$ NMR (75 MHz, $\mathrm{CDCl}_{3}$ ): $\delta=157.7,156.8$ (C), 154.3, 153.7 (C), 153.7, 153.4 (C), 140.4 (C), 137.3 (C), 136.5, 136.3 (C), 136.2, 135.9 (C), 134.9 (C), 132.1, 131.9 (2 $\left.\mathrm{CH}_{\text {arom }}\right), 130.9$ (2 $\left.\mathrm{CH}_{\text {arom }}\right), 130.8,130.6$ (2 $\left.\mathrm{CH}_{\text {arom }}\right), 114.9,114.3\left(2 \mathrm{CH}_{\text {arom }}\right), 114.8\left(2 \mathrm{CH}_{\text {arom }}\right), 114.0,113.3$ $\left(2 \mathrm{CH}_{\text {arom }}\right), 89.1\left(\mathrm{C}, \mathrm{C}_{5} \mathrm{H}_{4}\right), 68.7,68.6(5 \mathrm{CH}, \mathrm{Cp}), 68.2,68.1\left(2 \mathrm{CH}, \mathrm{C}_{5} \mathrm{H}_{4}\right), 67.7,67.5$ $\left(\mathrm{OCH}_{2}\right)$, 67.3, $67.2\left(2 \mathrm{CH}, \mathrm{C}_{5} \mathrm{H}_{4}\right), 29.3,29.1\left(\mathrm{CH}_{2}\right), 29.2\left(\mathrm{CH}_{2}\right), 28.9\left(\mathrm{CH}_{2}\right), 27.5,27.4\left(\mathrm{CH}_{2}\right)$, 
13.7 ppm $\left(\mathrm{CH}_{3}\right)$; IR (KBr): $\bar{v}=3422 \mathrm{~cm}^{-1}(\mathrm{OH})$; HRMS (CI, $\left.\mathrm{NH}_{3}\right): m / z:$ calcd for $\mathrm{C}_{36} \mathrm{H}_{37} \mathrm{FeO}_{3}$ $[M+\mathrm{H}]^{+}:$573.2093; found: 573.2089.

\section{1-[4-(Ferrocenylmethoxy)phenyl]-1,2-bis[4-(t-butyl-dimethylsilyloxy)phenyl]but-1-ene}

(17): A solution of DEAD $(0.72 \mathrm{~g}, 2.7 \mathrm{mmol})$ in dry THF $(3 \mathrm{~mL})$ was dropped at $0{ }^{\circ} \mathrm{C}$ into a solution of ferrocenylmethanol $9(0.59 \mathrm{~g}, 2.75 \mathrm{mmol}), 8 \mathrm{a}(1.1 \mathrm{~g}, 1.96 \mathrm{mmol})$ and $\mathrm{PPh}_{3}(0.72$ $\mathrm{g}, 2.7 \mathrm{mmol})$ in dry THF $(12 \mathrm{~mL})$. The reaction was stirred at room temperature for $96 \mathrm{~h}$. The solvent was evaporated under vacuum and the residue was purified by alumina-gel column chromatography (petroleum ether) to give $\mathbf{1 7}$ as a yellow solid (78 \%; isomer ratio: 1:1). This compound was recrystallized from an ether/pentane solution. ${ }^{1} \mathrm{H} \mathrm{NMR}\left(300 \mathrm{MHz}, \mathrm{CDCl}_{3}\right)$ : $\delta=7.23-6.45\left(\mathrm{~m}, 12 \mathrm{H} ; \mathrm{CH}_{\text {arom }}\right), 4.83,4.68\left(\mathrm{~s}, 2 \mathrm{H} ; \mathrm{OCH}_{2}\right), 4.22,4.14\left(\mathrm{t}, J=1.8 \mathrm{~Hz}, 2 \mathrm{H} ; \mathrm{C}_{5} \mathrm{H}_{4}\right)$, 4.08, 4.04 (t, J=1.8 Hz, $2 \mathrm{H} ; \mathrm{C}_{5} \mathrm{H}_{4}$ ), 4.07, 4.03 (s, $\left.5 \mathrm{H} ; \mathrm{Cp}\right), 2.50,2.49$ (q, J=7.3 Hz, $2 \mathrm{H}$; $\mathrm{CH}_{2}$ ), 0.89, 0.85 (s, $\left.9 \mathrm{H} ; t \mathrm{BuSi}\right), 0.88,0.87$ (t, $J=7.3 \mathrm{~Hz}, 3 \mathrm{H} ; \mathrm{CH}_{3}$ ), 0.86, 0.82 (s, $\left.9 \mathrm{H} ; t \mathrm{BuSi}\right)$, $0.26,0.20$ (s, $\left.6 \mathrm{H} ; \mathrm{SiMe}_{2}\right), 0.21,0.15 \mathrm{ppm}\left(\mathrm{s}, 6 \mathrm{H} ; \mathrm{SiMe}_{2}\right) ;{ }^{13} \mathrm{C} \mathrm{NMR}\left(75 \mathrm{MHz}, \mathrm{CDCl}_{3}\right)$ : $\delta=157.9,157.1$ (C), 154.5, 154.1 (C), 154.1, 153.7 (C), 140.9 (C), 137.8 (C), 137.3, 137.0 (C), 136.8, 136.4 (C), 136.0, 135.9 (C), $132.3\left(2 \mathrm{CH}_{\text {arom }}\right), 131.0\left(2 \mathrm{CH}_{\text {arom }}\right), 130.9\left(2 \mathrm{CH}_{\text {arom }}\right)$, 119.9, $119.8\left(2 \mathrm{CH}_{\text {arom }}\right), 119.8,119.2\left(2 \mathrm{CH}_{\text {arom }}\right), 114.5,113.8\left(2 \mathrm{CH}_{\text {arom }}\right), 83.0\left(\mathrm{C}, \mathrm{C}_{5} \mathrm{H}_{4}\right), 69.5$ $\left(2 \mathrm{CH}, \mathrm{C}_{5} \mathrm{H}_{4}\right), 68.9(5 \mathrm{CH}, \mathrm{Cp}), 68.8\left(2 \mathrm{CH}, \mathrm{C}_{5} \mathrm{H}_{4}\right), 66.8,66.6\left(\mathrm{OCH}_{2}\right), 29.2,29.1\left(\mathrm{CH}_{2}\right), 26.0$ $(2 t \mathrm{Bu}), 18.6(\mathrm{C}, t \mathrm{BuSi}), 18.5(\mathrm{C}, t \mathrm{BuSi}), 14.0\left(\mathrm{CH}_{3}\right),-4.0\left(\mathrm{SiMe}_{2}\right),-4.1 \mathrm{ppm}\left(\mathrm{SiMe}_{2}\right)$; IR (KBr): $\bar{v}=3087,3032,2956,2929,2896,2857\left(\mathrm{CH}_{2}, \mathrm{CH}_{3}\right), 1254 \mathrm{~cm}^{-1}\left(\mathrm{SiCH}_{3}\right)$; MS (CI, $\left.\mathrm{NH}_{3}\right): m / z: 759[M+\mathrm{H}]^{+}, 776\left[M+\mathrm{NH}_{4}\right]^{+}, 199\left[\mathrm{CpFeCpCH}_{2}\right]^{+\cdot}$; elemental analysis calcd $(\%)$ for $\mathrm{C}_{45} \mathrm{H}_{58} \mathrm{FeO}_{3} \mathrm{Si}_{2}$ : C 71.21, H 7.70; found: C 70.87, H 7.56.

1-[4-(Ferrocenylmethoxy)phenyl]-1,2-bis(4-hydroxyphenyl)but-1-ene (1): Compound 17 was dissolved in dry THF $(30 \mathrm{~mL})$ and a $1 \mathrm{M}$ solution of tetrabutylammonium fluoride $(2.8$ $\mathrm{mL}, 2.8 \mathrm{mmol}$ ) was added. The solution was stirred for $25 \mathrm{~min}$, hydrolyzed, and underwent the standard workup. The residue was purified on semipreparative HPLC with acetonitrile/water $80: 20$ as the eluent to give pure 1 (71\%). The isomers (isomer ratio: 1:1) were separated, but rapidly isomerized before evaporation of acetonitrile under reduced pressure. The mixture was extracted with dichloromethane and water, decanted, dried on $\mathrm{MgSO}_{4}$, and concentrated under reduced pressure. ${ }^{1} \mathrm{H}$ NMR $\left(300 \mathrm{MHz}, \mathrm{CDCl}_{3}\right): \delta=7.15,7.09$ (d, J=8.6 Hz, $2 \mathrm{H} ; \mathrm{CH}_{\text {arom }}$ ), 7.03-6.42 (m, $10 \mathrm{H} ; \mathrm{CH}_{\text {arom }}$ ), 4.82, 4.68 (s, $\left.2 \mathrm{H} ; \mathrm{OCH}_{2}\right), 4.34,4.26$ (t, J=1.8 Hz, $2 \mathrm{H} ; \mathrm{C}_{5} \mathrm{H}_{4}$ ), 4.21, 4.17 (t, J=1.8 Hz, $2 \mathrm{H} ; \mathrm{C}_{5} \mathrm{H}_{4}$ ), 4.20, 4.15 (s, $\left.5 \mathrm{H} ; \mathrm{Cp}\right), 2.46$ (q, 
$\left.J=7.4 \mathrm{~Hz}, 2 \mathrm{H} ; \mathrm{CH}_{2}\right), 0.94,0.93 \mathrm{ppm}\left(\mathrm{t}, J=7.4 \mathrm{~Hz}, 3 \mathrm{H} ; \mathrm{CH}_{3}\right) ;{ }^{13} \mathrm{C} \mathrm{NMR}\left(75 \mathrm{MHz}, \mathrm{CDCl}_{3}\right)$ : $\delta=157.5,156.7$ (C), 154.2, 153.7 (C), 153.7, 153.3 (C), 140.5 (C), 137.4 (C), 136.6 (C), 136.2, 136.1 (C), 134.9 (C), 132.2, $131.9\left(2 \mathrm{CH}_{\text {arom }}\right), 130.9\left(2 \mathrm{CH}_{\text {arom }}\right), 130.8,130.6\left(2 \mathrm{CH}_{\text {arom }}\right)$, 115.0, $114.9\left(2 \mathrm{CH}_{\text {arom }}\right), 114.9,114.3\left(2 \mathrm{CH}_{\text {arom }}\right), 114.3,113.7\left(2 \mathrm{CH}_{\text {arom }}\right), 82.6\left(\mathrm{C}, \mathrm{C}_{5} \mathrm{H}_{4}\right), 69.2$ $\left(2 \times 2 \mathrm{CH}, \mathrm{C}_{5} \mathrm{H}_{4}\right), 68.6(5 \mathrm{CH}, \mathrm{Cp}), 66.6,66.4\left(\mathrm{OCH}_{2}\right), 28.9\left(\mathrm{CH}_{2}\right), 13.7 \mathrm{ppm}\left(\mathrm{CH}_{3}\right)$; IR $(\mathrm{KBr}): \bar{v}=3414 \mathrm{~cm}^{-1}(\mathrm{OH})$; HRMS $\left(\mathrm{CI}, \mathrm{CH}_{4}\right): \mathrm{m} / z$ : calcd for $\mathrm{C}_{33} \mathrm{H}_{31} \mathrm{FeO}_{3}[M+\mathrm{H}]^{+}: 531.1623$; found: 531.1625 .

Preparation of 2 a and 19: A solution of DEAD (0.42 g, $2.4 \mathrm{mmol})$ in dry THF ( $3 \mathrm{~mL})$ was added dropwise to a $0{ }^{\circ} \mathrm{C}$ solution of ferrocenyl alcohol $\mathbf{1 0}(2.4 \mathrm{mmol})$, the known diphenol $8 \mathrm{~d}(0.633 \mathrm{~g}, 2 \mathrm{mmol})$, and $\mathrm{PPh}_{3}(0.74 \mathrm{~g}, 2.8 \mathrm{mmol})$ in dry THF $(12 \mathrm{~mL})$. The reaction mixture was stirred at room temperature for $48 \mathrm{~h}$. The solvent was evaporated under vacuum and the residue was purified on an aluminum oxide column with petroleum ether to give $\mathbf{2}$ a (isomer ratio: 1:1) and $\mathbf{1 9}$ as yellow solids. Compound 19 was recrystallized from petroleum ether and 2 a was re-purified on semipreparative HPLC with acetonitrile/water 90:10 as the eluent to give pure $\mathbf{2}$ a. The isomers were separated but remixed in the same flask (because of rapid isomerization) before evaporation of the maximum of acetonitrile under reduced pressure. The mixture was extracted with dichloromethane and water, decanted, dried on $\mathrm{MgSO}_{4}$, and concentrated under reduced pressure.

1-[4-(2-Ferrocenylethoxy)phenyl]-1-(4-hydroxyphenyl)-2-phenylbut-1-ene (2 a): Yield: $31 \%$; ${ }^{1} \mathrm{H}$ NMR (300 MHz, $\left.\mathrm{CDCl}_{3}\right): \delta=7.22-7.05\left(\mathrm{~m}, 7 \mathrm{H} ; \mathrm{CH}_{\text {arom }}\right), 6.89,6.81(\mathrm{~d}, J=8.8 \mathrm{~Hz}$, $2 \mathrm{H} ; \mathrm{CH}_{\text {arom }}$ ), 6.77, 6.73 (d, J=8.8 Hz, $\left.2 \mathrm{H} ; \mathrm{CH}_{\text {arom }}\right), 6.54,6.47$ (d, J=8.8 Hz, $2 \mathrm{H} ; \mathrm{CH}_{\text {arom }}$ ), 4.72, 4.49 (s, $1 \mathrm{H} ; \mathrm{OH}), 4.25-4.00$ (m, $\left.9 \mathrm{H} ; \mathrm{C}_{5} \mathrm{H}_{4} \mathrm{FeCp}\right), 4.11,3.95$ (t, J=7.0 Hz, $2 \mathrm{H} ; \mathrm{OCH}_{2}$ ), 2.84, 2.73 (t, J=7.0 Hz, $2 \mathrm{H} ; \mathrm{CH}_{2}$ ), 2.49 (q, J=7.4 Hz, $2 \mathrm{H} ; \mathrm{CH}_{2}$ ), 0.93 ppm (t, J=7.4 Hz, $3 \mathrm{H}$; $\mathrm{CH}_{3}$ ); ${ }^{13} \mathrm{C}$ NMR $\left(75 \mathrm{MHz}, \mathrm{CDCl}_{3}\right.$ ): $\delta=155.7,154.8(\mathrm{C}), 152.4,151.6$ (C), 140.8 (C), 139.2 (C), 135.9 (C), 134.5, 134.4 (C), 134.1, 133.9 (C), 130.2, $130.1\left(2 \mathrm{CH}_{\text {arom }}\right), 128.9,128.7$ (2 $\left.\mathrm{CH}_{\text {arom }}\right), 127.8\left(2 \mathrm{CH}_{\text {arom }}\right), 126.0\left(2 \mathrm{CH}_{\text {arom }}\right), 124.0(\mathrm{CH}), 113.1,112.4\left(2 \mathrm{CH}_{\text {arom }}\right), 112.2$, $111.4\left(2 \mathrm{CH}_{\text {arom }}\right), 82.9\left(\mathrm{C}, \mathrm{C}_{5} \mathrm{H}_{4}\right), 66.7\left(5 \mathrm{CH}, \mathrm{Cp}+2 \mathrm{CH}, \mathrm{C}_{5} \mathrm{H}_{4}\right), 66.6,66.4\left(\mathrm{OCH}_{2}\right), 65.6,65.5$ $\left(2 \mathrm{CH}, \mathrm{C}_{5} \mathrm{H}_{4}\right), 27.8,27.6\left(\mathrm{CH}_{2}\right), 27.1\left(\mathrm{CH}_{2}\right), 11.8 \mathrm{ppm}\left(\mathrm{CH}_{3}\right)$; IR $(\mathrm{KBr}): \bar{v}=3416,3262(\mathrm{OH})$, 2962, 2928, $2870 \mathrm{~cm}^{-1}\left(\mathrm{CH}_{2}, \mathrm{CH}_{3}\right)$; HRMS (EI, $\left.70 \mathrm{eV}\right): \mathrm{m} / z$ : calcd for $\mathrm{C}_{34} \mathrm{H}_{32} \mathrm{FeO}_{2}: 528.1752$ $[M]^{+}$; found: 528.1765; elemental analysis calcd (\%) for $\mathrm{C}_{34} \mathrm{H}_{32} \mathrm{FeO}_{2}: \mathrm{C} 77.27, \mathrm{H}$ 6.1; found: C 77.02, H 6.12. 
1,1-Bis[4-(2-ferrocenylethoxy)phenyl]-2-phenylbut-1-ene (19): Yield: $32 \%$; ${ }^{1} \mathrm{H}$ NMR (300 $\mathrm{MHz}, \mathrm{CDCl}_{3}$ ): $\delta=7.22-7.06\left(\mathrm{~m}, 7 \mathrm{H} ; \mathrm{CH}_{\text {arom }}\right), 6.88$ (d, J=8.7 Hz, $2 \mathrm{H} ; \mathrm{CH}_{\text {arom }}$ ), 6.77 (d, J=8.7 $\mathrm{Hz}, 2 \mathrm{H} ; \mathrm{CH}_{\text {arom }}$ ), 6.54 (d, J=8.7 Hz, $2 \mathrm{H} ; \mathrm{CH}_{\text {arom }}$ ), 4.18 (t, J=1.8 Hz, $\left.2 \mathrm{H} ; \mathrm{C}_{5} \mathrm{H}_{4}\right), 4.15$ (s, $5 \mathrm{H}$; $\mathrm{Cp}), 4.12-4.07\left(\mathrm{~m}, 9 \mathrm{H} ; \mathrm{Cp}+\mathrm{C}_{5} \mathrm{H}_{4}\right), 4.11\left(\mathrm{t}, J=7.0 \mathrm{~Hz}, 2 \mathrm{H} ; \mathrm{OCH}_{2}\right), 4.06(\mathrm{t}, J=1.8 \mathrm{~Hz}, 2 \mathrm{H}$; $\left.\mathrm{C}_{5} \mathrm{H}_{4}\right), 3.95\left(\mathrm{t}, J=7.0 \mathrm{~Hz}, 2 \mathrm{H} ; \mathrm{OCH}_{2}\right), 2.84\left(\mathrm{t}, J=7.0 \mathrm{~Hz}, 2 \mathrm{H} ; \mathrm{CH}_{2}\right), 2.73(\mathrm{t}, J=7.0 \mathrm{~Hz}, 2 \mathrm{H}$; $\mathrm{CH}_{2}$ ), 2.49 (q, J=7.4 Hz, $2 \mathrm{H} ; \mathrm{CH}_{2}$ ), $0.93 \mathrm{ppm}\left(\mathrm{t}, J=7.4 \mathrm{~Hz}, 3 \mathrm{H} ; \mathrm{CH}_{3}\right) ;{ }^{13} \mathrm{C} \mathrm{NMR}(75 \mathrm{MHz}$, $\mathrm{CDCl}_{3}$ ): $\delta=157.5$ (C), 156.7 (C), 142.7 (C), 141.0 (C), 136.3 (C), 134.8 (C), 133.3 (C), 131.9 (2 $\left.\mathrm{CH}_{\text {arom }}\right), 130.6$ (2 $\left.\mathrm{CH}_{\text {arom }}\right), 129.7\left(2 \mathrm{CH}_{\text {arom }}\right), 127.8\left(2 \mathrm{CH}_{\text {arom }}\right), 125.9\left(\mathrm{CH}_{\text {arom }}\right), 114.0$ $\left(2 \mathrm{CH}_{\text {arom }}\right), 113.3\left(2 \mathrm{CH}_{\text {arom }}\right), 84.7\left(2 \mathrm{C}, \mathrm{C}_{5} \mathrm{H}_{4}\right), 68.5\left(2 \times 5 \mathrm{CH}, \mathrm{Cp}+2 \times 2 \mathrm{CH}, \mathrm{C}_{5} \mathrm{H}_{4}\right), 68.4$ $\left(\mathrm{OCH}_{2}\right), 68.2\left(\mathrm{OCH}_{2}\right), 67.5\left(2 \mathrm{CH}, \mathrm{C}_{5} \mathrm{H}_{4}\right), 67.4\left(2 \mathrm{CH}, \mathrm{C}_{5} \mathrm{H}_{4}\right), 29.6\left(\mathrm{CH}_{2}\right), 29.5\left(\mathrm{CH}_{2}\right), 29.0$ $\left(\mathrm{CH}_{2}\right), 13.6 \mathrm{ppm}\left(\mathrm{CH}_{3}\right)$; IR (KBr): $\bar{v}=2360,2867,2928,2956,3092 \mathrm{~cm}^{-1}\left(\mathrm{CH}_{2}, \mathrm{CH}_{3}\right)$; MS (EI, $70 \mathrm{eV}) \mathrm{m} / z: 740[M]^{+}, 741[\mathrm{M+H}]^{+}, 199\left[\mathrm{CpFeCpCH}_{2}\right]^{+}, 121\left[\mathrm{CpFe}^{+}\right.$; elemental analysis calcd (\%) for $\mathrm{C}_{46} \mathrm{H}_{44} \mathrm{Fe}_{2} \mathrm{O}_{2}$ : C 74.60, H 5.98; found: C 74.42, H 5.94.

General procedure for the preparation of 20,20 a, and $20 \mathrm{~b}$ : In a Schlenk tube, under inert atmosphere, $\mathrm{KH}$ (25-35\% in oil, $0.03 \mathrm{~mL}, 1.2 \mathrm{mmol}$; 1.2 equiv) was dispersed in dry THF $(10 \mathrm{~mL})$. After the reaction mixture had been stirred for $10 \mathrm{~min}$, a solution of $\mathbf{8 , 8} \mathbf{d}$, or $\mathbf{8} \mathbf{b}(1$ mmol), respectively, in dry THF (10 mL) was added. The mixture was stirred under reflux for $15 \mathrm{~min}$ and then $\alpha$-chloroacetylferrocene $(443 \mathrm{mg}, 1.5 \mathrm{mmol})$ in dry THF $(10 \mathrm{~mL})$ was added. The solution was heated under reflux overnight. After hydrolysis and standard workup, orange solids of $\mathbf{2 0 , 2 0}$ a, or $\mathbf{2 0} \mathbf{b}$ were obtained.

\section{1-[4-(2-Ferrocenyl-2-oxoethoxy)phenyl]-1,2-bis-(4-trimethylacetoxyphenyl)but-1-ene}

(20): Yield: $300 \mathrm{mg}, 41 \%$, isolated as a mixture of both isomers (isomer ratio: 2:1); ${ }^{1} \mathrm{H} \mathrm{NMR}$ (300 MHz, $\left.\mathrm{CDCl}_{3}\right): \delta=7.23-6.65\left(\mathrm{~m}, 12 \mathrm{H} ; \mathrm{CH}_{\text {arom }}\right), 4.87\left(\mathrm{t}, J=1.9 \mathrm{~Hz}, 2 \mathrm{H} ; \mathrm{C}_{5} \mathrm{H}_{4}\right), 4.82$ (s, $2 \mathrm{H}$; O- $\mathrm{CH}_{2}$ ), 4.54 (t, J=1.9 Hz, $2 \mathrm{H} ; \mathrm{C}_{5} \mathrm{H}_{4}$ ), 4.16 (s, $5 \mathrm{H} ; \mathrm{Cp}$ ), 2.42 (q, J=7.3 Hz, $2 \mathrm{H} ; \mathrm{CH}_{2}$ ), 1.36, $1.33\left(\mathrm{~s}, 9 \mathrm{H} ; \mathrm{CH}_{3}\right.$ of $\left.t \mathrm{Bu}\right), 1.33,1.29\left(\mathrm{~s}, 9 \mathrm{H} ; \mathrm{CH}_{3}\right.$ of $\left.t \mathrm{Bu}\right), 0.89 \mathrm{ppm}(\mathrm{t}, J=7.3 \mathrm{~Hz}, 3 \mathrm{H}$; $\mathrm{CH}_{3}$ of Et); ${ }^{13} \mathrm{C} \mathrm{NMR}\left(75 \mathrm{MHz}, \mathrm{CDCl}_{3}\right): \delta=199.3(\mathrm{CO}), 177.0(\mathrm{COO}), 156.4(\mathrm{C}), 149.8(\mathrm{C})$, 149.3 (C), 141.1 (C), 140.9 (C), 139.5 (C), 137.6 (C), 136.0 (C), 132.1, 131.7 (2 $\left.\mathrm{CH}_{\text {arom}}\right)$, 130.5, $130.4\left(2 \times 2 \mathrm{CH}_{\text {arom }}\right), 121.1,121.4\left(2 \mathrm{CH}_{\text {arom }}\right), 121.0,120.0\left(2 \mathrm{CH}_{\text {arom }}\right), 114.5,113.9$ (2 $\left.\mathrm{CH}_{\text {arom }}\right), 77.2\left(\mathrm{C}, \mathrm{C}_{5} \mathrm{H}_{4}\right), 72.6\left(2 \mathrm{CH}, \mathrm{C}_{5} \mathrm{H}_{4}\right), 72.4\left(2 \mathrm{CH}, \mathrm{C}_{5} \mathrm{H}_{4}\right), 71.4\left(\mathrm{O}_{-} \mathrm{CH}_{2}\right), 70.0,69.3$ (5 CH, Cp), 39.1, $39.0(2 \mathrm{C}, t \mathrm{Bu}), 29.0\left(\mathrm{CH}_{2}\right), 27.1\left(2 \times 3 \mathrm{CH}_{3}, t \mathrm{Bu}\right), 13.6 \mathrm{ppm}\left(\mathrm{CH}_{3}, \mathrm{Et}\right)$; IR 
$(\mathrm{KBr}): \bar{v}=2972(\mathrm{C}-\mathrm{H} \mathrm{Ph}), 1751(\mathrm{CO}), 1685$ (FcCO), $1507 \mathrm{~cm}^{-1}(\mathrm{C}=\mathrm{C}$ arom); MS (EI): $m / z$ : $726[M]^{+}, 121[\mathrm{CpFe}]^{+}, 57[t \mathrm{Bu}]^{+} ; \mathrm{MS}\left(\mathrm{CI}, \mathrm{NH}_{3}\right): m / z: 744\left[M+\mathrm{NH}_{4}\right]^{+}, 727[M+\mathrm{H}]^{+}$; elemental analysis calcd (\%) for $\mathrm{C}_{44} \mathrm{H}_{46} \mathrm{O}_{6} \mathrm{Fe}$ : C 72.66, H 6.33; found: C 72.38, H 6.36.

\section{1-[4-(2-Ferrocenyl-2-oxoethoxy)phenyl]-1-(4-trimethylacetoxyphenyl)-2-phenylbut-1-ene}

(20 a): Yield: $50 \%$, isolated as a mixture of both isomers (isomer ratio: 5:1); ${ }^{1} \mathrm{H}$ NMR (300 $\mathrm{MHz}, \mathrm{CDCl}_{3}$ ): $\delta=7.25-6.61\left(\mathrm{~m}, 13 \mathrm{H} ; \mathrm{CH}_{\text {arom }}\right), 4.86$ (t, J=1.9 Hz, $\left.2 \mathrm{H} ; \mathrm{C}_{5} \mathrm{H}_{4}\right), 4.80$ (s, $2 \mathrm{H}$; O$\mathrm{CH}_{2}$ ), 4.54 (t, J=1.9 Hz, $\left.2 \mathrm{H} ; \mathrm{C}_{5} \mathrm{H}_{4}\right), 4.16(\mathrm{~s}, 5 \mathrm{H} ; \mathrm{Cp}), 2.42$ (q, J=7.4 Hz, $2 \mathrm{H} ; \mathrm{CH}_{2}$ ), 1.36 (s, $9 \mathrm{H} ; \mathrm{CH}_{3}$ of $\left.t \mathrm{Bu}\right), 0.88 \mathrm{ppm}\left(\mathrm{t}, J=7.4 \mathrm{~Hz}, 3 \mathrm{H} ; \mathrm{CH}_{3}\right.$ of $\left.\mathrm{Et}\right) ;{ }^{13} \mathrm{C} \mathrm{NMR}\left(75 \mathrm{MHz}, \mathrm{CDCl}_{3}\right)$ : $\delta=199.3$ (CO), 177.1 (COO), 156.3 (C), 149.7 (C), 142.2 (C), 142.0 (C), 141.0, 140.8 (C), 137.2 (C), 136.2, $136.1(\mathrm{C}), 132.0\left(2 \mathrm{CH}_{\text {arom }}\right), 130.4\left(2 \mathrm{CH}_{\text {arom }}\right), 129.6\left(2 \mathrm{CH}_{\text {arom }}\right), 127.9$ (2 $\left.\mathrm{CH}_{\text {arom }}\right), 126.1\left(\mathrm{CH}_{\text {arom }}\right), 121.1\left(2 \mathrm{CH}_{\text {arom }}\right), 113.7\left(2 \mathrm{CH}_{\text {arom }}\right), 77.2\left(\mathrm{C}, \mathrm{C}_{5} \mathrm{H}_{4}\right), 72.5(2 \mathrm{CH}$, $\left.\mathrm{C}_{5} \mathrm{H}_{4}\right), 71.5\left(\mathrm{O}-\mathrm{CH}_{2}\right), 70.0(5 \mathrm{CH}, \mathrm{Cp}), 69.4\left(2 \mathrm{CH}, \mathrm{C}_{5} \mathrm{H}_{4}\right), 39.1(\mathrm{C}, t \mathrm{Bu}), 29.1\left(\mathrm{CH}_{2}\right), 27.1$ $\left(3 \mathrm{CH}_{3}, t \mathrm{Bu}\right), 13.5 \mathrm{ppm}\left(\mathrm{CH}_{3} \mathrm{Et}\right) ; \mathrm{MS}(\mathrm{EI}): m / z: 626[M]^{+}, 121[\mathrm{FeCp}]^{+}, 57[t \mathrm{Bu}]^{+} ; \mathrm{HRMS}$ (EI, $70 \mathrm{eV}$ ): $\mathrm{m} / \mathrm{z}$ : calcd for $\mathrm{C}_{39} \mathrm{H}_{38} \mathrm{O}_{4} \mathrm{Fe}: 626.2120[M]^{+}$; found: 626.2117 .

\section{1-[4-(2-Ferrocenyl-2-oxoethoxy)phenyl]-2-(4-trimethylacetoxyphenyl)-1-phenylbut-1-ene}

(20 b): Yield: $45 \%$, isolated as a mixture of both isomers (isomer ratio: 3:2); ${ }^{1} \mathrm{H}$ NMR (300 $\mathrm{MHz}, \mathrm{CDCl}_{3}$ ): $\delta=7.36-6.66\left(\mathrm{~m}, 13 \mathrm{H} ; \mathrm{CH}_{\text {arom }}\right.$ ), 4.97, 4.82 (s, $2 \mathrm{H} ; \mathrm{O}-\mathrm{CH}_{2}$ ), 4.94, 4.88 (t, J=1.9 $\left.\mathrm{Hz}, 2 \mathrm{H} ; \mathrm{C}_{5} \mathrm{H}_{4}\right), 4.55,4.54$ (t, J=1.9 Hz, $\left.2 \mathrm{H} ; \mathrm{C}_{5} \mathrm{H}_{4}\right), 4.23,4.16$ (s, $\left.5 \mathrm{H} ; \mathrm{Cp}\right), 2.41$ (q, J=7.3 Hz, $\left.2 \mathrm{H} ; \mathrm{CH}_{2}\right), 1.34,1.32$ (s, $9 \mathrm{H} ; \mathrm{CH}_{3}$ of $\left.t \mathrm{Bu}\right), 0.93,0.92 \mathrm{ppm}\left(\mathrm{t}, J=7.4 \mathrm{~Hz}, 3 \mathrm{H} ; \mathrm{CH}_{3}\right.$ of Et); ${ }^{13} \mathrm{C}$ NMR (75 MHz, $\mathrm{CDCl}_{3}$ ): $\delta=199.4$ (CO), 177.0 (COO), 157.1 (C), 156.3 (C), 149.3 (C), 141.2 (C), 140.8 (C), 139.6 (C), 138.6, 138.5 (C), 132.0 ( $\left.2 \mathrm{CH}_{\text {arom }}\right), 130.8\left(2 \mathrm{CH}_{\text {arom }}\right), 130.7,130.5$ (2 $\left.\mathrm{CH}_{\text {arom }}\right), 129.4,128.1\left(2 \mathrm{CH}_{\text {arom }}\right), 127.4,126.6\left(\mathrm{CH}_{\text {arom }}\right), 121.0,120.8\left(2 \mathrm{CH}_{\text {arom }}\right), 114.5$, $113.9\left(2 \mathrm{CH}_{\text {arom }}\right), 77.2\left(\mathrm{C}, \mathrm{C}_{5} \mathrm{H}_{4}\right), 72.6,72.5\left(2 \mathrm{CH}, \mathrm{C}_{5} \mathrm{H}_{4}\right), 71.5\left(\mathrm{O}-\mathrm{CH}_{2}\right), 70.0(\mathrm{Cp}), 69.4$ $\left(2 \mathrm{CH}, \mathrm{C}_{5} \mathrm{H}_{4}\right), 39.0(\mathrm{C}, t \mathrm{Bu}), 29.0\left(\mathrm{CH}_{2}\right), 27.1\left(3 \mathrm{CH}_{3}, t \mathrm{Bu}\right), 13.6 \mathrm{ppm}\left(\mathrm{CH}_{3}, \mathrm{Et}\right) ; \mathrm{MS}(\mathrm{EI})$ : $m / z: 626[M]^{+}, 121[\mathrm{FeCp}]^{+}, 57[t \mathrm{Bu}]^{+}$; HRMS (EI, $\left.70 \mathrm{eV}\right): m / z$ : calcd for $\mathrm{C}_{39} \mathrm{H}_{38} \mathrm{O}_{4} \mathrm{Fe}$ : $626.2120[M]^{+}$; found: 626.2120 .

General procedure for the preparation of 5 a and $5 \mathbf{b}$ : Esters 20 a and $20 \mathrm{~b}(0.3 \mathrm{mmol})$ were dissolved in THF ( $5 \mathrm{~mL})$, respectively. $\mathrm{NaOH}(220 \mathrm{mg}$, excess) in water $(5 \mathrm{~mL})$ was added. The mixture was allowed to stir under reflux for $6 \mathrm{~h}$, after which time, it underwent the 
standard workup. By flash chromatography, orange/red solids of $\mathbf{5}$ a and $\mathbf{5} \mathbf{b}$ were isolated as a mixture of $Z$ and $E$ isomers.

1-(2-Ferrocenyl-2-oxoethoxyphenyl)-1-(4-hydroxyphenyl)-2-phenylbut-1-ene (5 a): Yield: $75 \%$ (isomer ratio: 55:45); ${ }^{1} \mathrm{H} \mathrm{NMR}\left(300 \mathrm{MHz}, \mathrm{CDCl}_{3}\right): \delta=7.19-6.47\left(\mathrm{~m}, 13 \mathrm{H} ; \mathrm{CH}_{\text {arom }}\right.$ ), 4.95, 4.87 (t, J=1.9 Hz, $\left.2 \mathrm{H} ; \mathrm{C}_{5} \mathrm{H}_{4}\right), 4.98,4.81$ (s, $\left.2 \mathrm{H} ; \mathrm{O}_{-} \mathrm{CH}_{2}\right), 4.60,4.55$ (t, J=1.9 Hz, $2 \mathrm{H}$; $\mathrm{C}_{5} \mathrm{H}_{4}$ ), 4.23, 4.16 (s, $5 \mathrm{H}$; Cp), 2.41, 2.39 (q, J=7.4 Hz, $2 \mathrm{H} ; \mathrm{CH}_{2}$ ), 0.90 ppm (t, J=7.4 Hz, $3 \mathrm{H}$; $\left.\mathrm{CH}_{3}\right) ;{ }^{13} \mathrm{C}$ NMR $\left(75 \mathrm{MHz}, \mathrm{CDCl}_{3}\right): \delta=199.9$ (CO), 156.9, 156.1 (C), 154.7, 153.8 (C), 142.6 (C), 141.3, 141.2 (C), 137.7 (C), 137.3, 136.8 (C), 136.0, 135.6 (C), $132.1\left(2 \mathrm{CH}_{\text {arom }}\right), 130.7$ (2 $\left.\mathrm{CH}_{\text {arom }}\right), 129.7$ (2 $\left.\mathrm{CH}_{\text {arom }}\right), 127.9,127.8\left(2 \mathrm{CH}_{\text {arom }}\right), 126.0\left(\mathrm{CH}_{\text {arom }}\right), 115.1,114.4\left(2 \mathrm{CH}_{\text {arom }}\right)$, 114.4, $113.7\left(2 \mathrm{CH}_{\text {arom }}\right), 75.8\left(\mathrm{C}, \mathrm{C}_{5} \mathrm{H}_{4}\right), 72.8,72.7\left(2 \mathrm{CH}, \mathrm{C}_{5} \mathrm{H}_{4}\right), 71.4,71.3\left(\mathrm{O}_{-} \mathrm{CH}_{2}\right), 70.2$, 70.0 (5 CH, Cp), $69.4\left(2 \mathrm{CH}, \mathrm{C}_{5} \mathrm{H}_{4}\right), 29.1\left(\mathrm{CH}_{2}\right), 13.6 \mathrm{ppm}\left(\mathrm{CH}_{3}\right)$; IR $(\mathrm{KBr}): \bar{v}=1665(\mathrm{CO})$, $1608(\mathrm{C}=\mathrm{C}), 1508 \mathrm{~cm}^{-1}\left(\mathrm{C}=\mathrm{C}\right.$ arom); MS (ESI): $m / z: 565[M+\mathrm{Na}]^{+}, 541[M+\mathrm{H}]^{+}$; HRMS (EI, $70 \mathrm{eV}$ ): $m / z$ : calcd for $\mathrm{C}_{34} \mathrm{H}_{30} \mathrm{O}_{3} \mathrm{Fe}: 542.1545[M]^{+}$; found: 542.1549 .

\section{1-(2-Ferrocenyl-2-oxoethoxyphenyl)-2-(4-hydroxyphenyl)-1-phenylbut-1-ene}

(5 b):

Yield: $73 \%$, isolated as a mixture of both isomers (isomer ratio: 55:45).

(Z)-Isomer: ${ }^{1} \mathrm{H}$ NMR (400 MHz, [D $\left.\left.\mathrm{D}_{6}\right] \mathrm{DMSO}\right): \delta=9.25(\mathrm{~s}, 1 \mathrm{H} ; \mathrm{OH}), 7.34(\mathrm{~d}, J=7.5 \mathrm{~Hz}, 2 \mathrm{H}$; meta-CH of $\left.\alpha-\mathrm{C}_{6} \mathrm{H}_{4}\right), 7.26\left(\mathrm{~d}, 2 \mathrm{H}\right.$; para-CH of $\left.\alpha-\mathrm{C}_{6} \mathrm{H}_{4}\right), 7.16(\mathrm{~d}, J=7.2 \mathrm{~Hz}, 2 \mathrm{H}$; ortho-CH of $\left.\alpha-\mathrm{C}_{6} \mathrm{H}_{4}\right), 6.91\left(\mathrm{~d}, J=8.3 \mathrm{~Hz}, 2 \mathrm{H} ; \beta-\mathrm{C}_{6} \mathrm{H}_{4}\right), 6.74\left(\mathrm{~d}, J=8.7 \mathrm{~Hz}, 2 \mathrm{H} ; \alpha^{\prime}-\mathrm{C}_{6} \mathrm{H}_{4}\right), 6.66$ (d, J=8.7 Hz, $2 \mathrm{H}$; $\mathrm{CH}-\mathrm{CO}$ of $\left.\alpha^{\prime}-\mathrm{C}_{6} \mathrm{H}_{4}\right), 6.56\left(\mathrm{~d}, J=8.3 \mathrm{~Hz}, 2 \mathrm{H}\right.$; CH-COH of $\left.\beta-\mathrm{C}_{6} \mathrm{H}_{4}\right), 5.04$ (s, $2 \mathrm{H}$; O-CH $2_{2}$ $\mathrm{CO}$ ), 4.88 (t, J=1.9 Hz, $2 \mathrm{H} ; \mathrm{C}_{5} \mathrm{H}_{4}$ ), 4.61 (t, J=1.9 Hz, $2 \mathrm{H} ; \mathrm{C}_{5} \mathrm{H}_{4}$ ), 4.23 (s, $5 \mathrm{H} ; \mathrm{Cp}$ ), 2.30 (q, $\left.J=7.4 \mathrm{~Hz}, 2 \mathrm{H} ; \mathrm{CH}_{2}\right), 0.83 \mathrm{ppm}\left(\mathrm{t}, J=7.4 \mathrm{~Hz}, 3 \mathrm{H} ; \mathrm{CH}_{3}\right)$; the $Z$ isomer was identified by $2 \mathrm{D}$ NMR spectroscopy.

(E)-Isomer: ${ }^{1} \mathrm{H}$ NMR (400 MHz, [D 6 DMSO): $\delta=7.33-6.61\left(\mathrm{~m}, 13 \mathrm{H} ; \mathrm{CH}_{\text {arom }}\right), 4.94(\mathrm{t}, J=1.9$ $\mathrm{Hz}, 2 \mathrm{H} ; \mathrm{C}_{5} \mathrm{H}_{4}$ ), 4.81 (s, $2 \mathrm{H}$; O- $\left.\mathrm{CH}_{2}-\mathrm{CO}\right), 4.55$ (t, J=1.9 Hz, $2 \mathrm{H} ; \mathrm{C}_{5} \mathrm{H}_{4}$ ), 4.16 (s, $5 \mathrm{H} ; \mathrm{Cp}$ ), 2.45 (q, J=7.4 Hz, $\left.2 \mathrm{H} ; \mathrm{CH}_{2}\right), 0.93$ ppm (t, J=7.4 Hz, $\left.3 \mathrm{H} ; \mathrm{CH}_{3}\right)$.

(Z+E)-Mixture: ${ }^{13} \mathrm{C}$ NMR (100.61 MHz, $\left.\mathrm{CDCl}_{3}\right): \delta=200.5$ (CO), 160.6 (C), 153.9 (C), 143.4 (C), 141.6 (C), 139.5 (C), 138.4 (C), 137.6 (C), 132.0, $130.9\left(2 \mathrm{CH}_{\text {arom }}\right), 130.8,129.5(2 \mathrm{CH}$, 
$\left.\mathrm{C}_{5} \mathrm{H}_{4}\right), 128.1,127.6\left(2 \mathrm{CH}, \mathrm{C}_{5} \mathrm{H}_{4}\right), 127.4,126.5\left(2 \mathrm{CH}, \mathrm{C}_{5} \mathrm{H}_{4}\right), 125.7,125.6\left(\mathrm{CH}, \mathrm{C}_{5} \mathrm{H}_{4}\right)$, 114.9, $114.8\left(2 \mathrm{CH}, \mathrm{C}_{5} \mathrm{H}_{4}\right), 114.5,113.8\left(2 \mathrm{CH}, \mathrm{C}_{5} \mathrm{H}_{4}\right), 77.2\left(\mathrm{C}, \mathrm{C}_{5} \mathrm{H}_{4}\right), 72.6\left(2 \mathrm{CH}, \mathrm{C}_{5} \mathrm{H}_{4}\right)$, $71.5\left(\mathrm{O}-\mathrm{CH}_{2}\right), 70.1$ (5 CH, Cp), $69.4\left(2 \mathrm{CH}, \mathrm{C}_{5} \mathrm{H}_{4}\right), 28.9\left(\mathrm{CH}_{2}\right), 13.6 \mathrm{ppm}\left(\mathrm{CH}_{3}\right) ; \mathrm{IR}\left(\mathrm{CH}_{2} \mathrm{Cl}_{2}\right)$ : $\bar{v}=3595(\mathrm{OH}), 1686(\mathrm{CO}), 1606(\mathrm{C}=\mathrm{C}), 1509 \mathrm{~cm}^{-1}(\mathrm{C}=\mathrm{C}$ arom $)$; $\mathrm{MS}\left(\mathrm{CI}, \mathrm{NH}_{3}\right): m / z: 560$ $\left[M+\mathrm{NH}_{4}\right]^{+}, 543[M+\mathrm{H}]^{+}$; elemental analysis calcd $(\%)$ for $\mathrm{C}_{34} \mathrm{H}_{30} \mathrm{O}_{3} \mathrm{Fe}: \mathrm{C}$ 75.22, H 5.53; found: C 75.35, H 5.57.

\section{Biochemical experiments}

Materials: Stock solutions $\left(1 \times 10^{-3} \mathrm{M}\right)$ of the ferrocenyl complexes to be tested were prepared in DMSO and were kept at $4{ }^{\circ} \mathrm{C}$ in the dark; under these conditions they are stable for at least two months. Serial dilutions in DMSO were prepared just prior to use. A stock solution $\left(1 \times 10^{-3} \mathrm{M}\right)$ of $17 \beta-\mathrm{E}_{2}$ was prepared in ethanol. Dulbecco's modified eagle medium (DMEM) was purchased from Gibco BRL, fetal calf serum from Dutscher, Brumath (France), glutamine, $\mathrm{E}_{2}$, and protamine sulfate were from Sigma. MCF-7 and MDA-MB-231 cells were from the Human Tumor Cell Bank. Sheep uteri weighing approximately $7 \mathrm{~g}$ were obtained from the slaughterhouse at Mantes-la-Jolie (France). They were immediately frozen and kept in liquid nitrogen prior to use.

\section{Determination of the relative binding affinity (RBA) of the compounds for ER $\alpha$ : RBA}

values were measured on ER $\alpha$ from lamb uterine cytosol prepared in buffer A (0.05 M TrisHCL, $0.25 \mathrm{M}$ sucrose, $0.1 \% \beta$-mercaptoethanol, $\mathrm{pH} 7.4$ at $25^{\circ} \mathrm{C}$ ) as described previously. ${ }^{[30]}$ Aliquots $(200 \mu \mathrm{L})$ of cytosol were incubated for $3 \mathrm{~h}$ at $0{ }^{\circ} \mathrm{C}$ with $[6,7-3 \mathrm{H}]-\mathrm{E}_{2}\left(2 \times 10^{-} \mathrm{M}\right.$, specific activity $1.62 \mathrm{TBq} \mathrm{mmol}^{-1}$, NEN Life Science, Boston MA) in the presence of nine concentrations of the ferrocenyl complexes to be tested (between $6 \times 10^{-7}$ and $6 \times 10^{-9} \mathrm{M}$ for the complexes with RBA values higher than $5 \%$ and between $6 \times 10^{-6}$ and $6 \times 10^{-8} \mathrm{M}$ for the compounds with RBA values lower than $5 \%$ ) or of $17 \beta-\mathrm{E}_{2}$ (between $8 \times 10^{-8}$ and $7.5 \times 10^{-10}$ $M)$. At the end of the incubation period, the fractions of $\left[{ }^{3} \mathrm{H}\right]-\mathrm{E}_{2}$ bound to the estrogen receptors ( $Y$ values) were precipitated by addition of a $200 \mu \mathrm{L}$ of a cold solution of protamine sulfate $\left(1 \mathrm{mg} \mathrm{mL}^{-1}\right.$ in water). After a $10 \mathrm{~min}$ period of incubation at $4{ }^{\circ} \mathrm{C}$, the precipitates were recovered by filtration on $25 \mathrm{~mm}$ circle glass microfibre filters GF/C filters by using a Millipore 12 well filtration ramp. The filters were rinsed twice with cold phosphate buffer and then transferred in $20 \mathrm{~mL}$ plastic vials. After addition of $5 \mathrm{~mL}$ of scintillation liquid (BCS 
Amersham) the radioactivity of each fraction was counted in a Packard tri-carb 2100TR liquid scintillation analyzer. The concentration of unlabeled steroid required to displace $50 \%$ of the bound $\left[{ }^{3} \mathrm{H}\right]-\mathrm{E}_{2}$ was calculated for $17 \beta-\mathrm{E}_{2}$ and for each complex by plotting the logit values of $Y$ (logit $Y=\ln (Y / 100-Y)$ versus the mass of the competing complex. The RBA (relative binding affinity) was calculated as follows: RBA of a compound=concentration of $\mathrm{E}_{2}$ required to displace $50 \%$ of $\left[{ }^{3} \mathrm{H}\right]-\mathrm{E}_{2} \times 100 /$ concentration of the compound required to displace $50 \%$ of $\left[{ }^{3} \mathrm{H}\right]-\mathrm{E}_{2}$. The RBA value of $\mathrm{E}_{2}$ is by definition equal to $100 \%$.

Measurement of the octanol/water partition coefficient $(\log P o / w)$ of the compounds: The $\log P o / w$ values of the compounds were determined by reverse-phase HPLC on a C-8 column (Nucleosil 5.C8, from Macherey Nagel, France) according to a previously described method. ${ }^{[46,47]}$ Measurement of the chromatographic capacity factors $(\mathrm{kN})$ for each compound was done at various concentrations in the range of $85-60 \%$ methanol (containing $0.25 \%$ octanol) and an aqueous phase consisting of $0.15 \% n$-decylamine in $0.02 \mathrm{M}$ MOPS (3morpholinopropanesulfonic acid) buffer $\mathrm{pH} 7.4$ (prepared in 1-octanol/saturated water). These capacity factors $(\mathrm{kN})$ are extrapolated to $100 \%$ of the aqueous component given the value of $\mathrm{k}^{\prime}{ }_{\mathrm{w}} \times \log P o / w(y)$ is then obtained by the formula: $y=0.13418+0.98452 \times \log k_{\mathrm{w}}$.

Culture conditions: Cells were maintained in monolayer culture in DMEM with phenol red/Glutamax I, supplemented with $9 \%$ of decomplemented fetal calf serum and $0.9 \%$ kanamycine, at $37^{\circ} \mathrm{C}$ in a $5 \% \mathrm{CO}_{2}$ air humidified incubator. For proliferation assays, cells were plated in 24-well sterile plates at a density of $1.1 \times 10^{4}$ cells for PC-3 or MDA-MB-231 and of $3 \times 10^{4}$ cells for MCF-7 in $1 \mathrm{~mL}$ of DMEM without phenol red, supplemented with $9 \%$ of fetal calf serum desteroided on dextran charcoal, $0.9 \%$ Glutamax I, and $0.9 \%$ kanamycine, and were incubated for $24 \mathrm{~h}$. The following day (D0), $1 \mathrm{~mL}$ of the same medium containing the compounds to be tested diluted in DMSO was added to the plates (final volumes of DMSO: $0.1 \% ; 4$ wells for each conditions). After 3 days (D3), the incubation medium was removed and $2 \mathrm{~mL}$ of fresh medium containing the compounds was added. At different days (D3, D4, D5, and D6), the protein content of each well was quantified by methylene blue staining as follows. Cell monolayers were fixed and stained for $1 \mathrm{~h}$ in methanol with methylene blue $\left(2.5 \mathrm{mg} \mathrm{mL}^{-1}\right)$, and then washed thoroughly with water. Two milliliters of $\mathrm{HCl}(0.1 \mathrm{M})$ was then added, and the plate was incubated for $1 \mathrm{~h}$ at $37^{\circ} \mathrm{C}$. Then the absorbance of each well was measured at $655 \mathrm{~nm}$ with a Biorad spectrophotometer 
(microplate reader). The results are expressed as the percentage of proteins versus the control. Experiments were performed at least in duplicate.

Molecular modeling: Theoretical docking experiments with the two isomers of $\mathbf{2}, \mathbf{2} \mathbf{a}, \mathbf{2} \mathbf{b}, \mathbf{5}$, $\mathbf{5} \mathbf{a}$, and $\mathbf{5} \mathbf{b}$ in the ER were performed by using the LBD structure of ER $\alpha$ bound to OH-Tam (Protein Data Bank code: 3ERT, $)^{[7]}$ and Mac Spartan Pro(Wavefunction Co., Irvine CA 92612, USA). The affinity of the bioligand for the cavity was determined by using MMFF molecular mechanics, with calculations for the bioligand-ER cavity combination, and for the ER cavity and the bioligand performed separately, each retaining the conformation previously determined for the molecular complex. This gives a value of the energy variation $\Delta E$ of the reaction: ligand + cavity $\rightarrow$ ligand-cavity complex.

Electrochemistry: Cyclic voltammograms (CVs) were obtained by using a three-electrode cell with a $0.5 \mathrm{~mm}$ Pt working electrode, gold-plated nickel mesh counter electrode, and saturated calomel reference electrode, with an Autolab PGStat20 potentiostat driven by GPES software (General Purpose Electrochemical System, Version 4.8, EcoChemie B.V., Utrecht, the Netherlands) Solutions consisted of DMF $(6 \mathrm{~mL})$, analyte $(1 \mathrm{mM})$, and $\mathrm{TBABF}_{4}$ supporting electrolyte $(0.1 \mathrm{M})$. Variable scan rate CVs were obtained from 0.05 to $20 \mathrm{~V} \mathrm{~s}^{-1}$. Between each scan the working electrode was gently polished with a sheet of "kimwipe light" (Kimberly-Clark Co.).

\section{Acknowledgements}

We thank M.-N. Rager for 2D analysis, A. Cordaville for technical assistance, and the Agence Nationale de la Recherche for financial support (No. ANR-06-BLAN-0384-01, "FerVect").

[1] V. C. Jordan, Curr. Probl. Cancer 1992, 16, 129 - 176.

[2] V. C. Jordan, J. Med. Chem. 2003, 46, 883 - 908.

[3] J. I. MacGregor, V. C. Jordan, Pharmacol. Rev. 1998, 50, 151 - 196.

[4] V. C. Jordan, J. Med. Chem. 2003, 46, 1081 - 1108.

[5] J. S. Lewis, V. C. Jordan, Mutat. Res. 2005, 591, 247 - 263. 
[6] A. M. Brzozowski, A. C. Pike, Z. Dauter, R. E. Hubbard, T. Bonn, O. Engstrom, L. Ohman, G. L. Greene, J.-A. Gustafsson, M. Carlquist, Nature 1997, 389, 753 - 758.

[7] A. K. Shiau, D. Barstad, P. M. Loria, L. Cheng, P. J. Kushner, D. A. Agard, G. L. Greene, Cell 1998, 95, 927 - 937.

[8] A. C. W. Pike, A. M. Brzozowski, J. Walton, R. E. Hubbard, A. G. Thorsell, Y. L. Li, J.-A. Gustafsson, M. Carlquist, Structure 2001, 9, 145 - 153.

[9] M. J. Meegan, D. G. Lloyd, Curr. Med. Chem. 2003, 10, $181-210$.

[10] R. A. Magarian, L. B. Overacre, S. Singh, K. L. Meyer, Curr. Med. Chem. 1994, 1, 61 104.

[11] D. W. Robertson, J. A. Katzenellenbogen, J. R. Hayes, B. S. Katzenellenbogen, J. Med. Chem. 1982, 25, $167-171$.

[12] A. B. Foster, R. McCague, A. Seago, G. Leclercq, S. Stoessel, F. Roy, Anticancer Drug Des. 1986, 1, 245 - 257.

[13] M. Jarman, O. T. Leung, G. Leclercq, N. Devleeschouwer, S. Stoessel, R. C. Coombes, R. A. Skilton, Anticancer Drug Des. 1986, 1, 259 - 268.

[14] V. Agouridas, I. Laios, A. Cleeren, E. Kizilian, E. Magnier, J.-C. Blazejewski, G. Leclercq, Bioorg. Med. Chem. 2006, 14, 7531 - 7538.

[15] T. M. Willson, J. D. Norris, B. L. Wagner, I. Asplin, P. Baer, H. R. Brown, S. A. Jones, B. Henke, H. Sauls, S. Wolfe, D. C. Morris , D. P. McDonnell, Endocrinology 1997, 138,3901 .

[16] T. M. Willson, B. R. Henke, T. M. Momtahen, P. S. Charifson, K. W. Batchelor, D. B. Lubahn, L. B. Moore, B. B. Oliver, H. R. Sauls, J. A. Triantafillou, S. G. Wolfe, P. G. Baer, J. Med. Chem. 1994, 37, 1550 - 1552.

[17] Y.-L. Wu, X. Yang, Z. Ren, D. P. McDonnell, J. D. Norris, T. M. Willson, G. L. Greene, Mol. Cell 2005, 18, 413 - 424.

[18] K. S. Kraft, P. C. Ruenitz, M. G. Bartlett, J. Med. Chem. 1999, 42, 3126 - 3133.

[19] V. N. Rubin, P. C. Ruenitz, F. D. Boudinot, J. L. Boyd, Bioorg. Med. Chem. 2001, 9, $1579-1587$. 
[20] S. Top, A. Vessières, G. Leclercq, J. Quivy, J. Tang, J. Vaissermann, M. Huché, G. Jaouen, Chem. Eur. J. 2003, 9, 5223 - 5236.

[21] S. Top, A. Vessières, C. Cabestaing, I. Laios, G. Leclercq, C. Provot, G. Jaouen, J. Organomet. Chem. 2001, 637, $500-506$.

[22] G. Jaouen, S. Top, A. Vessières, G. Leclercq, J. Quivy, L. Jin, A. Croisy, C. R. Acad. Sci. Ser. IIc 2000, 89 - 93.

[23] S. Top, B. Dauer, J. Vaissermann, G. Jaouen, J. Organomet. Chem. 1997, 541, 355 361.

[24] S. Top, J. Tang, A. Vessières, D. Carrez, C. Provot, G. Jaouen, Chem. Commun. 1996, $955-956$.

[25] A. Vessières, S. Top, P. Pigeon, E. A. Hillard, L. Boubeker, D. Spera, G. Jaouen, J. Med. Chem. 2005, 48, 3937 - 3940.

[26] A. Nguyen, A. Vessières, E. A. Hillard, S. Top, P. Pigeon, G. Jaouen, Chimia 2007, 61, $716-724$.

[27] P. Köpf-Maier, H. Köpf, E. W. Neuse, Angew. Chem. 1984, 96, 446 - 447; Angew. Chem. Int. Ed. Engl. 1984, 23, 456 - 457.

[28] P. Köf-Maiyer, H. Köpf, E. W. Neuse, J. Cancer Res. Clin. Oncol. 1984, 108, 336 340.

[29] E. A. Hillard, P. Pigeon, A. Vessières, C. Amatore, G. Jaouen, Dalton Trans. 2007, $5073-5081$.

[30] G. Tabbi, C. Cassino, G. Cavigiolio, D. Colangelo, A. Ghiglia, I. Viano, D. Osella, J. Med. Chem. 2002, 45, 5786 - 5796.

[31] D. Osella, M. Ferrali, P. Zanello, F. Laschi, M. Fontani, C. Nervi, G. Cavigiolio, Inorg. Chim. Acta 2000, 306, $42-48$.

[32] A. M. Joy, D. M. L. Goodgame, I. J. Stratford, Int. J. Radiation Oncology Biol. Phys. 1989, $16,1053-1056$.

[33] H. Tamura, M. Miwa, Chem. Lett. 1997, 1177 - 1178. 
[34] E. A. Hillard, A. Vessières, L. Thouin, G. Jaouen, C. Amatore, Angew. Chem. 2006, 118, 291 - 296; Angew. Chem. Int. Ed. 2006, 45, 285 - 290.

[35] A. Vessières, S. Top, W. Beck, E. A. Hillard, G. Jaouen, Dalton Trans. 2006, 4, 529 541.

[36] E. A. Hillard, A. Vessières, S. Top, P. Pigeon, K. Kowalski, M. Huché, G. Jaouen, J. Organomet. Chem. 2007, 692, 1315 - 1326.

[37] A. Nguyen, V. Marsaud, C. Bouclier, S. Top, A. Vessières, P. Pigeon, R. Gref, P. Legrand, G. Jaouen, J.-M. Renoir, Int. J. Pharm. 2008, 347, 128 - 135.

[38] A. Nguyen, S. Top, A. Vessières, P. Pigeon, M. Huché, E. A. Hillard, G. Jaouen, J. Organomet. Chem. 2007, 692, $1219-1225$.

[39] S. Masi, S. Top, L. Boubeker, G. Jaouen, S. Mundwiler, B. Spingler, R. Alberto, Eur. J. Inorg. Chem. 2004, 2013 - 2017.

[40] S. Top, S. Masi, G. Jaouen, Eur. J. Inorg. Chem. 2002, 1848 - 1853.

[41] K. W. Nettles, J. B. Bruning, G. Gil, E. E. O’Neill, J. Nowak, A. Hughs, Y. Kim, E. R. DeSombre, R. Dilis, R. N. Hanson, A. Joachimiak, G. L. Green, EMBO Rep. 2007, 8, $563-568$.

[42] S. Gauthier, J. Mailhot, F. Labrie, J. Org. Chem. 1996, 61, 3890 - 3893.

[43] D. G. Lloyd, H. M. Smith, T. O’Sullivan, D. M. Zisterer, M. J. Meegan, Med. Chem. 2005, $1,335-353$.

[44] W. L. Davis, R. F. Shago, E. H. G. Langner, J. C. Swarts, Polyhedron 2005, 24, 1611 1616.

[45] S. G. A. Moinuddin, S. Hishiyama, M.-H. Cho, L. B. Davin, N. G. Lewis, Org. Biomol. Chem. 2003, 1, $2307-2313$.

[46] D. J. Minick, J. H. Frenz, M. A. Patrick, D. A. Brent, J. Med. Chem. 1988, 31, 1923 1933.

[47] M. G. Pomper, H. VanBrocklin, A. M. Thieme, R. D. Thomas, D. O. Kiesewetter, K. E. Carlson, C. J. Mathias, M. J. Welch, J. A. Katzenellenbogen, J. Med. Chem. 1990, 33, $3143-3155$. 


\section{Supporting Information}

\section{Cell culture results for MDA-MB231}

Table SI1. Effect of the compounds on the growth of MDA-MB-231 (hormone-independent breast cancer cells) after 5 days of culture at $10 \mu \mathrm{M}$ (except for estradiol, $10 \mathrm{nM}$ ). Mean of two separate experiments ( 4 wells for each experiment $) \pm$ range.

\begin{tabular}{ll}
\hline Compound & Cell growth (\%)* \\
17ß-estradiol & $100 \pm 2$ \\
$(Z+E)-\mathbf{1}$ & $82 \pm 2$ \\
$(Z+E)-\mathbf{2}$ & $83.2 \pm 1.2$ \\
$(Z+E)-\mathbf{3}$ & $91 \pm 0.05$ \\
$(Z+E)-\mathbf{4}$ & $96.6 \pm 2.5$ \\
$(Z+E)-\mathbf{2 a}$ & $86.1 \pm 3.3$ \\
$(Z+E)-\mathbf{2 b}$ & $84 \pm 2$ \\
$(Z)-\mathbf{5}$ & $80 \pm 7$ \\
$(E)-\mathbf{5}$ & $87 \pm 6$ \\
$(Z+E)-\mathbf{5 a}$ & $106 \pm 4$ \\
$(Z)-\mathbf{5 b}$ & $91 \pm 2$ \\
$(E)-\mathbf{5 b}$ & $105 \pm 4$ \\
\hline
\end{tabular}

* with the control, cells without added, compound set at $100 \%$. 


\section{RBA values for $\operatorname{Er} \beta$}

ER $\beta$ were purchased in solution from Pan Vera (Madison, WI, USA), $10 \mu 1$ of the solution containing $3500 \mathrm{pmol} / \mathrm{mL}$ were added to $16 \mathrm{~mL}$ of buffer B (10\% glycerol, $50 \mathrm{mM}$ Bis-Tris-Propane $\mathrm{pH}=9,400$ $\mathrm{mM} \mathrm{KCl}, 2 \mathrm{mM}$ DTT, $1 \mathrm{mM}$ EDTA, 0.1\% BSA) in a silanized flask. Aliquots (200 mL) of this solution were transferred in polypropylene tubes and RBA values were determined as indicated in paragraph 4.3.2

\begin{tabular}{|l|ll}
\hline Table SI2. Relative Binding Affinity values (RBA) for the beta form of the Estrogen Receptor \\
$(\mathrm{ER} \beta)$ \\
\hline
\end{tabular}




\section{Electrochemical results}

Table SI3. Influence of ferrocenyl chain length on redox potential of ferrocene.

$\begin{array}{lll}\text { Compound } & \text { Number of carbon atoms } & \mathrm{E}_{1 / 2}\left(\mathrm{FeCp}_{2}{ }^{0 /+}\right) \text { vs. SCE } \\ \mathbf{1} & 1 & 0.506 \\ \mathbf{2 a} & 2 & 0.451 \\ \mathbf{2 b} & 2 & 0.442 \\ \mathbf{2} & 2 & 0.447 \\ \mathbf{3} & 3 & 0.432 \\ \mathbf{4} & 4 & 0.454\end{array}$

Table SI4. Influence of number of phenol groups on observed phenol oxidation potential for 1-4.

$\begin{array}{lll}\text { Compound } & \text { Number of phenol groups } & \mathrm{E}^{\mathrm{o}, \mathrm{a}} \text { phenol vs. SCE } \\ \mathbf{1} & 2 & 0.867 \\ \mathbf{2 a} & 1 & 1.136 \\ \mathbf{2 b} & 1 & 1.050 \\ \mathbf{2} & 2 & 0.880 \\ \mathbf{3} & 2 & 0.867 \\ \mathbf{4} & 2 & 0.867\end{array}$

\begin{tabular}{|l|l|l|l|l|}
\hline \multicolumn{5}{|l|}{ Table SI5. Observed oxidation potentials vs. SCE for the acyl series at 0.1 and $20 \mathrm{~V} / \mathrm{s}}$. \\
\hline Compound & $\begin{array}{l}\mathrm{E}^{\mathrm{o}, \mathrm{a}}\left(\mathrm{FeCp}_{2}{ }^{0 /+}\right) \\
0.1 \mathrm{~V} / \mathrm{s}\end{array}$ & $\begin{array}{l}\mathrm{E}_{1 / 2}\left(\mathrm{FeCp}_{2}{ }^{0 /+}\right) \\
20 \mathrm{~V} / \mathrm{s}\end{array}$ & $\begin{array}{l}\mathrm{E}^{\mathrm{o,a}} \text { phenol } \\
0.1 \mathrm{~V} / \mathrm{s}\end{array}$ & $\begin{array}{l}\mathrm{E}^{\text {o,a }} \\
20 \mathrm{~V} / \mathrm{s}\end{array}$ \\
\hline $\mathbf{5}$ & $0.767 \mathrm{irrev}$. & $0.736 \mathrm{rev}$. & Not observed & $1.04 \mathrm{irrev}$. \\
\hline $\mathbf{5 a}$ & 0.783 irrev. & $0.727 \mathrm{rev}$. & $1.17 \mathrm{irrev}$. & $1.31 \mathrm{irrev}$. \\
\hline $\mathbf{5 b}$ & 0.811 irrev. & $0.731 \mathrm{rev}$. & 1.14 irrev. & $1.23 \mathrm{irrev}$. \\
\hline
\end{tabular}




\section{Color representation of Figure 1}

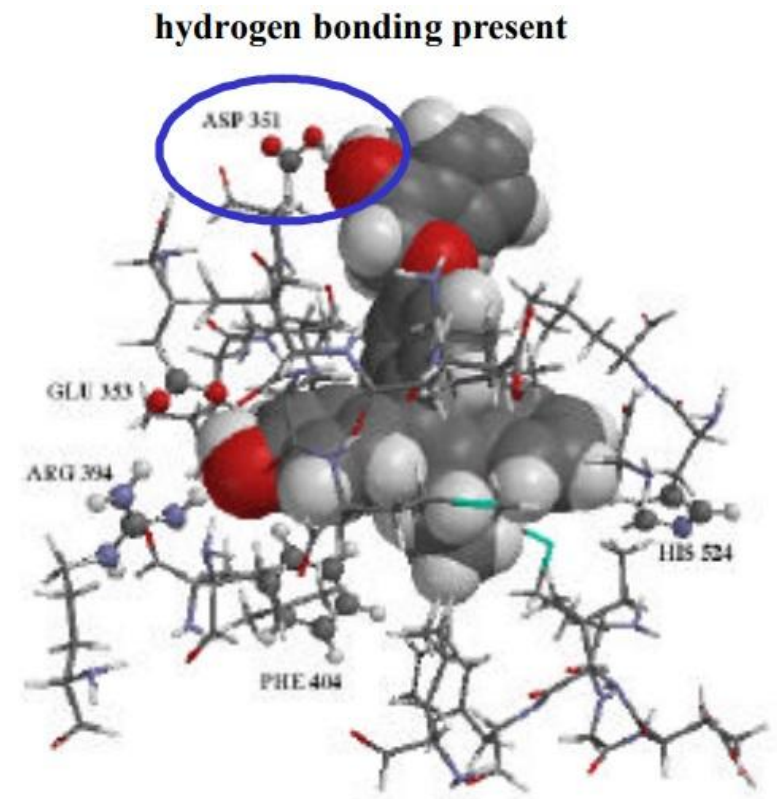

$(Z)-5 a$

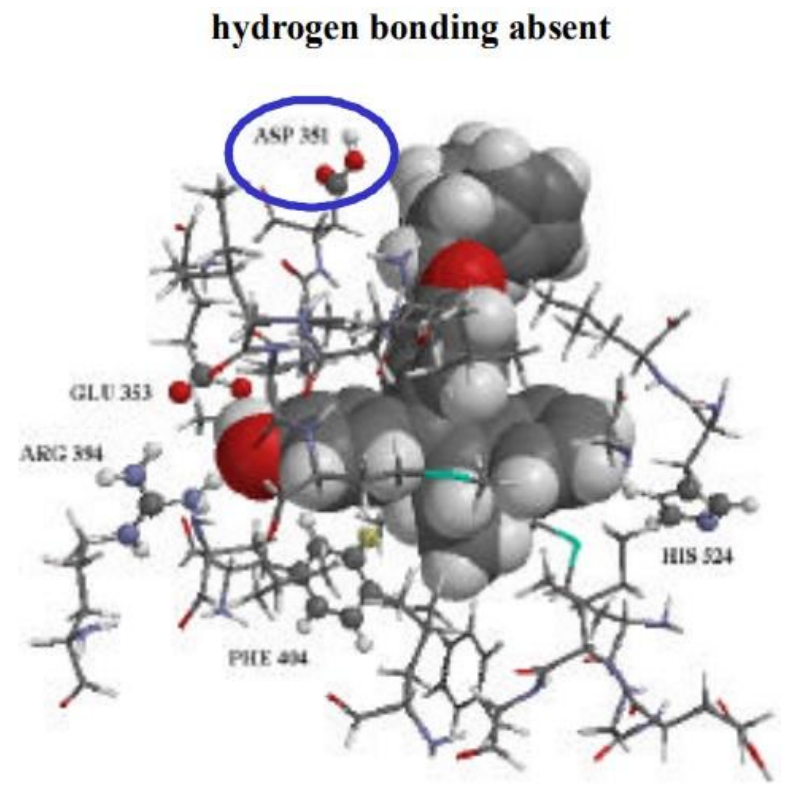

(Z)-2a 